$6-2018$

\title{
Cold Genocide: Falun Gong in China
}

\author{
Maria Cheung \\ University of Manitoba \\ Torsten Trey \\ Doctors Against Forced Organ Harvesting \\ David Matas \\ University of Manitoba \\ Richard An \\ EME Professional Corp Legal Services
}

Follow this and additional works at: https://digitalcommons.usf.edu/gsp

\section{Recommended Citation}

Cheung, Maria; Trey, Torsten; Matas, David; and An, Richard (2018) "Cold Genocide: Falun Gong in China," Genocide Studies and Prevention: An International Journal: Vol. 12: Iss. 1: 38-62.

DOI:

https://doi.org/10.5038/1911-9933.12.1.1513

Available at: https://digitalcommons.usf.edu/gsp/vol12/iss1/6

This Articles is brought to you for free and open access by the Open Access Journals at Digital Commons @ University of South Florida. It has been accepted for inclusion in Genocide Studies and Prevention: An International Journal by an authorized editor of Digital Commons @ University of South Florida. For more information, please contact digitalcommons@usf.edu. 


\section{Cold Genocide: Falun Gong in China}

Acknowledgements

This article is dedicated to the Chinese citizens who were innocently killed for their spiritual beliefs. 


\title{
Cold Genocide: Falun Gong in China
}

\author{
Maria Cheung \\ University of Manitoba \\ Winnipeg, Manitoba, Canada \\ Torsten Trey \\ Doctors Against Forced Organ Harvesting \\ Washington, D.C., USA \\ David Matas \\ University of Manitoba \\ Winnipeg, Manitoba, Canada \\ Richard An \\ York University \\ Toronto, Ontario, Canada
}

\section{Introduction}

The classical school of genocide studies which traces back to Raphael Lemkin focuses on eradication of a group through the mass murder of its members in a short period. This conception fails to capture the realities of genocides which have emerged in recent decades. ${ }^{1}$ Recent genocide studies have begun to embrace a wider variety of genocidal acts than mass murder and acknowledges new dynamics and meanings in such acts. Recognizing the limitation of the classical school, Alexander Hinton invites a re-evaluation of the concept of genocide to illuminate events that are invisible, ignored or forgotten. In his critical genocide studies, Hinton employs a more inclusive definition of genocide, "while recognizing that all definitions have weaknesses, we might simply define genocide as the more or less coordinated attempt to destroy a dehumanized and excluded group of people because of who they are." ${ }^{2} \mathrm{He}$ underscores that the definition should include the "destruction of any sort of group as defined by the protagonists in genocide." 3 The focus of Hinton is the destruction of the group as a group. Mass murder of all members of the group is one, but not the only way to eradicate the group, to erase the common features which bind the group. The notion of short term intensity is replaced by the concept of a coordinated attempt, which can be much longer lasting.

In recent scholarship, Kjell Anderson and Sheri Rosenberg advance a concept of "cold genocide."4 They describe cold genocide as slow motion genocide or genocide by attrition. ${ }^{5}$ Rosenberg explains such genocides as "a slow process of annihilation that reflects the unfolding phenomenon of the mass killing of a protected group rather than the immediate unleashing of violent death." ${ }^{1}$ Cold genocides can take place through subtle forms of structural violence that destroy the group through gradual measures. Examples are undermining access to the necessities of daily life such as work, housing, schooling, food, and health services, or gradual disappearances. ${ }^{7}$ Cold genocides stand in contrast to "hot" genocides, destructive acts of high intensity which annihilate the victim group in a

\footnotetext{
${ }^{1}$ Kjell Anderson, "Colonialism and Cold Genocide: The Case of West Papua," Genocide Studies and Prevention: An International Journal 9, no. 2 (2015), 19, accessed December 12, 2016, doi: http://dx.doi. org/10.5038/19119933.9.2.1270.

${ }^{2}$ Alexander Laban Hinton, "Critical Genocide Studies," Genocide Studies and Prevention: An International Journal 7, no. 1 (2012), 910.

${ }^{3}$ Ibid., 9.

${ }^{4}$ Anderson, Colonialism and Cold Genocide, 9; Sheri P. Rosenberg, "Genocide Is a Process, Not an Event," Genocide Studies and Prevention: An International Journal 7, no. 1 (2012), 19.

${ }^{5}$ Ibid.

${ }^{6}$ Rosenberg, Genocide Is a Process, 19.

${ }^{7}$ Anderson, Colonialism and Cold Genocide, 20.
}

Maria Cheung, Torsten Trey, David Matas, and Richard An, "Cold Genocide: Falun Gong in China" Genocide Studies and Prevention 12, 1 (2018): 38-62. @2018 Genocide Studies and Prevention. 
short time span. There is a sliding scale of genocides which vary with the perpetrators' perceptions of the victim groups, the intentions of the perpetrators, the speed with which the genocides occur the tools being utilized, and the intensity of genocidal motivations. ${ }^{8}$

Although the question when genocides begin or end can be debated, a genocide that has lasted longer than 10 years has been rare. In the last five decades, the typical length of genocides which have occurred and captured international attention have lasted no more than five years. ${ }^{9}$ The table in Appendix A documents the known genocides in the twentieth and twenty-first centuries. Of the nine well documented genocides which took place in the twentieth century, six had lasted less than five years; four had lasted less than a year. Most of these genocides would be considered hot. The lack of documentation on cold genocides raises an issue which Hinton asked: why are certain genocides widely discussed while some are being ignored ${ }^{10}$ One answer is a failure to keep pace with the evolving manifestations of genocide. The limitations in the classical conception of genocide are observed in the eradication campaign against Falun Gong. Falun Gong is a spiritual practice which became the target of an eradication campaign in China beginning in 1999. In comparison to the other genocides set out in Appendix A, the genocide against Falun Gong stands out as anomalous because it is virtually ignored. An academic database search of literature for the key words "genocide" and "Falun Gong" in the title, only one early article has a direct focus on this topic. ${ }^{11}$ Its findings are inconclusive.

The present article seeks to explore the eradication campaign against Falun Gong in terms of a cold genocide. From an interdisciplinary perspective encompassing social work, medicine and law, we elucidate the multi-faceted nature of this concealed genocide. The article is divided into two segments. The first segment is empirical. This segment attempts to explain what Falun Gong is, summarizes eleven years of investigation into forced organ harvesting of Falun Gong practitioners in China, and provides an overview of other aspects of the eradication campaign against Falun Gong. The second segment provides an assessment of the intent of genocide directed against the Falun Gong community and a demonstration of the cold nature of the genocide observed in the eradication campaign against Falun Gong. In particular, the article analyses the (1) the multidimensional nature of the destruction; (2) its subtlety and invisibility; and (3) its normalization by the society in which it takes place

\section{What is Falun Gong?}

Falun Gong (also known as Falun Dafa) is a body-mind-spiritual practice which started in China in 1992 and was widely practiced in the 1990s. It is a self-cultivation practice, which upholds the principles of "truthfulness, compassion, and tolerance."12 The practice comprises five sets of meditative exercises. The teachings of Falun Gong emphasize cultivation of the mind, without adherence to religious formalities. ${ }^{13}$ The tenets of Falun Gong trace back to those traditional Chinese cultural beliefs grounded in Buddhist and Taoist philosophies. From the beginning of its introduction to the Chinese populace, Falun Gong was popularized in China as a form of qigong - the cultivation and exercise of the body's vital energy. The practice of Falun Gong is cost free. Its moral principles, spiritual teachings and beneficial health effects appealed to the

\footnotetext{
${ }^{8}$ Ibid., 19.

${ }^{9}$ Refer Appendix A. Sources: Samuel Totten and William S. Parsons, Centuries of Genocide: Essays and Eyewitness Accounts, 4th ed. (New York: Routledge, 2013); Samuel Totten and William S. Parsons, Centuries of Genocide: Critical Essays and Eyewitness Accounts, 3rd ed. (New York: Routledge, 2009); Ben Saul, "Was the Conflict in East Timor 'Genocide' and Why Does it Matter?" Melbourne Journal of International Law 2, no. 2 (2001), 477-479.

${ }^{10}$ Hinton, Critical Genocide Studies, 11.

${ }^{11}$ Robert Bejesky, "United States Obligations under International Law and the Falun Gong v. Jiang Zemin Lawsuit: A Justified Reaction to a Threat to Public Security or Genocide? You Decide," Journal of International Law \& Policy 11, no. 2 (2005), 295-342.

12 “Overview of Falun Gong," Falun Dafa Information Center, April 2008, accessed December 20, 2016, http://www. faluninfo.net/topic/22.

${ }^{13}$ Maria Cheung, "The Intersection between Mindfulness and Human Rights: The Case of Falun Gong and Its Implications for Social Work," Journal of Religion E Spirituality in Social Work: Social Thought 35, no.12 (2016), 60, accessed January 27, 2017, doi: 10.1080/15426432.2015.1067586.
} 
Chinese population. ${ }^{14}$ However, in mid-1990s, when the Chinese Communist Party/State found that seventy million Chinese citizens were practising Falun Gong, there occurred a change in Party/ State attitudes toward the practice. The Party started harassing Falun Gong practitioners, leading to a crackdown in $1999 .{ }^{15}$

Before the persecution began in 1999, Western scholars were not familiar with Falun Gong. After the persecution began, they described Falun Gong as a new religious movement. ${ }^{16}$ Benjamin Penny went through many Falun Gong teachings and concluded that Falun Gong is a religion. ${ }^{17}$ Paul Hedges' review of Penny's book The Religion of Falun Gong pointed out that this categorization relies on the Western understanding of religion. Since the term "religion" is culturally bound, we need to deconstruct it. Hedges remarked that "the naming process [naming Falun Gong a religion] is political and contested."18 Falun Gong has a loose organizational structure-no membership system, and thus no membership fee, no hierarchy, and no institutional structure. The Chinese term for religion (zongjiao) commonly refers to historic faiths which are formalized with clergy and a set of institutions. ${ }^{19}$ The differences with historic faiths led practitioners of Falun Gong themselves to eschew the religious label for the practice of Falun Gong. ${ }^{20}$

The field research in North America of David Ownby confirmed that the Falun Gong community is extremely decentralized. ${ }^{21}$ A Canadian tribunal in case of discrimination against an elderly Falun Gong practitioner characterized Falun Gong as a creed..$^{22}$ Despite the discrepancy in perception and definition of religion in the East and in the West, the Falun Gong community is satisfied with the description of Falun Gong as a creed. Genocide scholar Gregory Stanton, for his work, has adopted the US Code definition of religious group. The Code defines a religious group as "a set of individuals whose identity is defined by common religious creeds, beliefs, doctrines, practices, or rituals." ${ }^{23}$ In the presentation of many lawsuits and legal hearings in Western countries, the persecution of Falun Gong is categorized as religious persecution..$^{24}$

Especially since the repression begun in 1999, narratives about Falun Gong have polarized, the Chinese official narrative at one pole and the narrative of the Falun Gong community at the other. ${ }^{25}$ The polarization poses difficulties for scholars and journalists who have investigated the repression of Falun Gong. In the early 2000s, most Western scholars adopted a balanced approach to the Chinese State and Falun Gong narratives. Verification of either narrative has been a challenge. After many years of field study on Falun Gong, David Ownby concluded that the evidence brought

\footnotetext{
${ }^{14}$ Scott Lowe, "Chinese and International Contexts for the Rise of Falun Gong," Nova Religio: The Journal of Alternative and Emergent Religions 6, no. 2 (2003), 271.

${ }^{15}$ David Matas and Maria Cheung, "Concepts and Precepts: Canadian Tribunals, Human Rights and Falun Gong," Canadian Journal of Human Rights 1, no. 1 (2012), 70.

${ }^{16}$ Matas and Cheung, Concepts and Precepts, 63; The whole special issue on Falun Gong in Nova Religio Symposium: Falun Gong, Nova Religio: The Journal of Alternative and Emergent Religions 6, no. 2 (2003).

${ }^{17}$ Benjamin Penny, The Religion of Falun Gong (Chicago: The University of Chicago Press, 2012), 6.

${ }^{18}$ Paul Hedges, "A Review of the Religion of Falun Gong," Journal of Buddhist Ethics 21, (2014), 701-702.

${ }^{19}$ Unofficial Religions in China: Beyond the Party's Rules, before the Congressional-Executive Commission on China, $109^{\text {th }}$ Cong., 1st Session, 2 (2005) (statement of David Ownby, Professor of History, University of Montreal), accessed February 18, 2018, https://www.cecc.gov/sites/chinacommission.house.gov/files/documents/roundtables/2005/ CECC Roundtable Testimony - David Ownby - 5.23.05.pdf.

${ }^{20}$ Li Hongzhi, “Lecture at the First Conference in North America," (lecture, New York, March 29- 30, 1998), accessed September 12, 2017, http://en.falundafa.org/eng/lectures/19980329L.html.

${ }^{21}$ David Ownby, Falun Gong and the Future of China, (New York: Oxford University Press, 2008), 133.

${ }^{22}$ Huang v. 1233065 Ontario, Human Rights Tribunal of Ontario, January 18, 2006, HRTO1, para 9. [the Chinese Senior's Association case].

${ }^{23}$ Gregory H. Stanton, “What is Genocide?” Genocide Watch, 2002, accessed December 18, 2016, http://www. genocidewatch.org/genocide/whatisit.html.

${ }^{24}$ U.S. Department of Justice, Office of Public Affairs, "Justice Department Resolves Discrimination Case Against Flushing, N.Y. Restaurant That Ejected Patrons Because of Religion," Justice News, August 12, 2010, accessed September 10, 2017, https://www.justice.gov/opa/pr/justice-department-resolves-discrimination-case-againstflushing-ny-restaurant-ejected.

${ }^{25}$ Matas and Cheung, Concepts and Precepts, 72-73.
} 
forward by the Falun Gong community on persecution was more convincing than that put forward by the Chinese state, many of which are repetitive assertions demonizing Falun Gong. ${ }^{26}$ Ownby saw the Falun Gong practice as completely comprehensible and rejected the Chinese regime portrayal of Falun Gong as a cult. ${ }^{27}$ David Ownby, Andrew Junker and other scholars concluded that Falun Gong is a non-political, loosely organized group that was perceived as political or politicized only after the onset of the repression. ${ }^{28}$ The group's engagement in what appears to be political resistance started only after the Chinese regime began to demonize, ostracize, dehumanize and torture practitioners. ${ }^{29}$

\section{Eradication Campaign Against Falun Gong}

Origins of the Eradication Campaign

All civic activities, including religion and qigong, are highly regulated in China. ${ }^{30}$ Falun Gong was supported by the Chinese authorities in its first few years, until its exponential growth in the mid-90s. ${ }^{31}$ Falun Gong was initially allowed to register with the Chinese Qigong Science Research Society (CQSRS), a state agency where authorized qigong groups are registered. ${ }^{32}$ Defamatory publications attacking the Falun Gong and harassment of Falun Gong practitioners groups led to its withdrawal from the CQSRS in 1996 under pressure. After withdrawal, defamation and harassment increased..$^{33}$

The trigger for the nationwide campaign for eradication of Falun Gong was the "Zhongnanhai Incident" in April 1999. In response to the detention of forty-five practitioners in Tianjin who had been protesting a locally published defamatory publication, approximately ten thousand Falun Gong practitioners gathered peacefully at the Government petition office near Zhongnanhai, the Government compound of Beijing. ${ }^{34}$ There is no evidence that the gathering was centrally planned. The gathering was rather the result of confluent independent initiatives by individual Falun Gong practitioners who appealed to fellow practitioners. ${ }^{35}$ The gathering asked for freedom to practice Falun Gong and release of the detained Falun Gong practitioners. Jiang Zemin, then President of China and head of the Chinese Communist Party, framed this incident as an ideological challenge to the Party. ${ }^{36}$ Thereafter, Jiang delivered a speech to the Politburo calling for a widespread repression campaign named dou zheng (斗争; "to purge or violently suppress") against Falun Gong. ${ }^{37}$ In July 1999, Jiang issued a formal order to eradicate Falun Gong. ${ }^{38}$ A

${ }^{26}$ Ibid.; Ownby, Falun Gong and the Future of China, 162-163.

${ }^{27}$ Ownby, Falun Gong and the Future of China, 127.

${ }^{28}$ Ibid., 170; Andrew Junker, "Follower Agency and Charismatic Mobilization in Falun Gong," Sociology of Religion 75, no. 3 (2014), 426, accessed February 20, 2017, doi:10.1093/socrel/sru021.

${ }^{29}$ James W Tong, Revenge of the Forbidden City: The Suppression of the Falun Gong in China, 1999-2005 (New York: Oxford University Press, 2009), 29.

${ }^{30}$ Matas and Cheung, Concepts and Precepts, 67.

${ }^{31}$ Ibid., 70.

${ }^{32}$ Ownby, Falun Gong and the Future of China, 44.

${ }^{33}$ Ibid., 167-168.

${ }^{34}$ Maria Hsia Chang, Falun Gong: The End of Days (New Haven: Yale University Press, 2004), 12.

${ }^{35}$ Li Hongzhi, “Some Thoughts of Mine," FalunDafa, June 2, 1999, accessed May 12, 2017, http://falundafa.org/eng/ eng/jiyz2 02.htm.

${ }^{36}$ In a Jiang's letter to the Politburo Standing Committee, he wrote, "The [Zhongnanhai] incident indicates how weak is the ideological and political work and the work for the masses of some of our local governments and departments... Can't the Marxism our Communists have, the materialism, atheism we believe in really win over that sort of stuff airezd by Falun Gong?... Our leading cadres at all levels especially high level officials should become sober now!" Source: North Spring Edit, Letter from Comrade Jiang Zemin to Standing Members and Related Leaders of the Political Bureau of the CCCP, April 27, 1999, Beijing Spring, accessed March 3, 2017, http:// beijingspring.com/bj2/2001/60/2003727210907.htm.

${ }^{37}$ North Spring Edit, "Speech of Comrade Jiang Zemin at the Central Political Bureau Meeting on Seizing the Solution and Solving the 'Falungong' Issue," (speech, June 7, 1999), Bejing Spring, July 27, 2003. Accessed March 3, 2017. http://beijingspring.com/bj2/2001/60/2003727210907.htm.

${ }^{38}$ Freedom House, The Battle for China's Spirit: Religious Revival, Repression, and Resistance under Xi Jinping, Special 
doctrine within the Communist Party was turned into state policy without any formal legislative procedure. $^{39}$

To carry out the eradication campaign, Jiang tasked Party officials Li Lanqing and Luo Gan to form a "Leading Group for Handling the Falun Gong Issue" (falun gong wenti lingdao xiaozu). The group was to formulate strategies and methods to extinguish Falun Gong. The Leadership Group eventually developed into a Party-directed structure called the "610 Office" (established on June 10, 1999)..$^{40}$ The 610 Office is the primary entity responsible for organizing the eradication campaign against Falun Gong. ${ }^{41}$ The 610 Office operates extra-judicially; it is not an organ of the Chinese State, but rather of the Chinese Communist Party. ${ }^{42}$ The 610 Office directs all levels of State institutions including the judiciary, the civil service, business and education. It has overarching power and authority over all other Party entities and all State bodies. All State agencies and all other Party agencies have to comply with the 610 Office's directives and orders.

The campaign, initially, was to convert Falun Gong believers using all means, including torture. ${ }^{43}$ The goal was to complete the campaign within three months. ${ }^{44}$ However, the goal was not achieved. Falun Gong practitioners showed unexpected resilience; they continuously demonstrated at Tiananmen Square and local authorities' offices for the reinstatement of Falun Gong. In consequence, the Party decided to step up the intensity of the campaign. On November 30, 1999, Li Lanqing, under the direction of Jiang, announced to 3,000 officials at the Great Hall of Beijing a new and more vicious campaign to eliminate Falun Gong. ${ }^{45}$ A new "strike hard" campaign to eradicate Falun Gong was launched under the auspices of the 610 Office. ${ }^{46}$

\section{Intensification of the Eradication Campaign}

In the intensified eradication campaign, torture and deaths resulting from torture became the norm. Falun Gong practitioners have been exposed to a wide range of torture methods, including brainwashing, forced labour, sleep deprivation, sexual violence, psychiatric and other medical experimentation, and forced organ harvesting. ${ }^{47}$ Torture deaths have occurred after beating, forcefeeding, electric baton application, suffocation and other methods. ${ }^{48}$ Minghui.org, an online portal

Report, February 2017, 112, accessed April 29, 2017, https://freedomhouse.org/sites/default/files/FH 2017 BattleForChinasSpirit Falun Gong 0.pdf.

${ }^{39}$ Bryan Edelman and James Richardson, "Falun Gong and the Law: Development of Legal Social Control in China," Nova Religio: The Journal of Alternative and Emergent Religions 6, no. 2 (2003), 317.

${ }^{40}$ Sarah Cook and Leeshai Lemish, "The 610 Office: Policing the Chinese Spirit," Jamestown Foundation China Brief 11, no. 17 (2011), 6, accessed May 17, 2017, https://jamestown.org/program/the-610-office-policing-the-chinesespirit/.

${ }^{41}$ Matas and Cheung, Concepts and Precepts, 69.

${ }^{42}$ Yiyang Xia, "The Illegality of China's Falun Gong Crackdown - and Today's Rule of Law Repercussions," Written Statement submitted by Senior Director of Policy and Research at the Human Rights Law Foundation to European Parliament, 2011, accessed April 25, 2017, http://www.europarl.europa.eu/meetdocs/2009 2014/ documents/droi/dv/506 yiyangxia/506 yiyangxia en.pdf.

${ }^{43}$ Human Rights Law Foundation, "Jiang Zemin and the Party's Douzheng Campaign against Falun Gong," May 6, 2015, accessed December 12, 2016, http://en.minghui.org/html/articles/2015/5/6/150033.html.

${ }^{44}$ Tianliang Zhang, "Pouring the Entire Nation's Efforts into Persecution," in An Unprecedented Evil Persecution: A Genocide Against Goodness in Humankind, ed. Torste Trey and Theresa Chu, (USA: Clear Insight Publishing, 2016), 64.

${ }^{45}$ David Matas and David Kilgour, Bloody Harvest: The Killing of Falun Gong for Their Organs (Niagara Falls: Seraphim Editions, 2009), 23.

${ }^{46}$ Amnesty International, People's Republic of China: Human Rights in China in 2001- A New Step Backwards, briefing, September 3, 2001, accessed March 20, 2017, https://www.amnesty.org/download/Documents/128000/ asa170282001en.pdf.

${ }^{47}$ The United States Commission on International Religious Freedom, 2017 Annual Report, April 26, 2017, 36, accessed April 29, 2017, http://www.uscirf.gov/sites/default/files/2017.USCIRFAnnualReport.pdf; “Mechanics of Persecution," Falun Dafa Info Center, April 9, 2015, accessed February 10, 2017, http://faluninfo.net/topic/7/.

${ }^{48}$ Minghui, "Clearwisdom Collection: Illustrations of Torture Methods Used to Persecute Falun Gong Practitioners (Part II)," Clearwisdom, August 30, 2004, accessed February 12, 2017, http://www.clearwisdom.net/emh/ 
of Falun Gong practitioners, has verified data of over 4,000 cases of Falun Gong practitioners who were tortured to death. ${ }^{49}$

According to Ethan Gutmann's survey-based estimation, from 2000 to 2008, an average of 450,000 to a million Falun Gong practitioners were detained in forced labour camps (also known as reeducation through labour) at any given time. ${ }^{50}$ In 2006, the UN Special Rapporteur on Torture Manfred Nowak reported that in $66 \%$ of all alleged torture cases in Chinese detention camps, Falun Gong practitioners were victims, followed next by Uighurs at $11 \%{ }^{51}$ The Government of China states that they closed down the forced labour camps in 2014. ${ }^{2}$ However, according to the Minghui.org website, Falun Gong practitioners who had been in such camps were not released. They were instead transferred to what are officially called Legal Education Centres and are commonly known as brainwashing centres. ${ }^{53}$ Amnesty International has reported that, since its abolition, the forced labour system has been replaced by other forms of arbitrary detention and punishment. ${ }^{54}$

As Noakes and Ford noted, by 2002, the regime had proclaimed victory over Falun Gong. References to the practice had become muted in both the international and domestic media. ${ }^{55}$ This media silence led many to believe that the eradication campaign against Falun Gong was a fait accompli and that the campaign against Falun Gong had ended. However, a recent study which tracked the state of the anti-Falun Gong campaign indicates the opposite. Despite the lesser volume of media reports, the campaign is very much alive. ${ }^{56}$ The regime continues to invest resources in combating Falun Gong and to launch regular, nationally coordinated campaigns. For instance, in recent years the regime launched a nationwide transformation campaign called "20132015 final battle on education and transformation" ${ }^{57}$ The campaign required authorities to enter villages, households, schools, businesses and Party cells in search of Falun Gong practitioners to transform..$^{58}$ The degree of activity and effort to eradicate Falun Gong suggests that the campaign remains a priority.

This conclusion is corroborated by Chinese sources. By collating individual reports of harm, arrest and detention of Falun Gong practitioners, Minghui's statistics show that the eradication campaign has maintained intensity. According to Minghui, there were 10,869 reported cases of arrest, harassment and detention against Falun Gong practitioners in China in the first half of $2017 .{ }^{59}$ In the same period, over 1,807,396 Yuan (approx. US \$273,000) in cash, as well as cell

articles/2004/8/30/51887p.html.

${ }^{49}$ Minghui Correspondent, "4126 Deaths Confirmed," Clearwisdom, September 6, 2017, accessed September 6, 2017, http://www.clearwisdom.net/html/index.html.

${ }^{50}$ Ethan Gutmann, The Slaughter: Mass Killings, Organ Harvesting, and China's Secret Solution to Its Dissident Problem (New York: Prometheus Books, 2014), 320.

${ }^{51}$ Manfred Nowak, Mission To China: Report of the Special Rapporteur on Torture and Other Cruel, Inhuman or Degrading Treatment or Punishment, March 10, 2006 (UN Doc. E/CN.4/2006/6/Add.6), 13, accessed February 7, 2017, http://www.dafoh.org/wpcontent/uploads/UNSpecialRapporteurManfredNowak_MissiontoChina 2006. pdf.

${ }^{52}$ Amnesty International, China: 'Changing the Soup but not The Medicine?' Abolishing Re-education through Labour in China (London: Amnesty International Publications, December 17, 2013), 34, accessed November 20, 2017, https://www.amnesty.org/en/documents/ASA17/042/2013/en/.

${ }^{53}$ Minghui Correspondent in China, "Persecution Continues Unabated after Labor Camp Closures (Part 1)," Clearwisdom, January 18, 2014, accessed March 20, 2017, http://en.minghui.org/html/articles/2014/1/18/144478p. html.

${ }^{54}$ Amnesty International, China: Changing the Soup, 35.

${ }^{55}$ Stephen Noakes and Caylan Ford, "Managing Political Opposition Groups in China: Explaining the Continuing Anti-Falun Gong Campaign," The China Quarterly 223 (2015), 662, accessed August 20, 2017, doi:10.1017/ S0305741015000788.

${ }^{56}$ Ibid.

${ }^{57}$ Ibid., 665 .

${ }^{58}$ Ibid.

${ }^{59}$ Minghui Correspondent in China, “10,869 Cases of Falun Gong Practitioners Arrested and Harassed for Their Faith Reported in the First Half of 2017," Clearwisdom, November 6, 2017, accessed November 15, 2017, http:// 
Cheung et al.

phones, computers and other daily necessities were confiscated from Falun Gong practitioners during house raids.$^{60}$ In 2001, when the intensity of the eradication campaign was at its supposed peak, the total number of reported arrests, harassment and detention cases against Falun Gong was only $9,105 .{ }^{61}$

\section{Forced Organ Harvesting}

A critical aspect of the eradication campaign against Falun Gong is forced organ harvestingextracting organs, including essential organs, without consent, resulting in death. In June 2016, David Kilgour, Ethan Gutmann and David Matas released a detailed update of their previous work on organ transplant activities in China. The update considered data from 164 hospitals approved by the Ministry of Health to conduct organ transplants in 2007.62 Based on over 2000 sources from Chinese hospital websites, academic articles published in China and Chinese media reports, the update was a continuation of eleven years of investigation into forced organ harvesting in China. ${ }^{63}$ The update confirmed that forced organ harvesting continues in China on an industrial scale, despite announcements by Chinese officials that China has stopped using prisoners for organ transplantation. ${ }^{64}$

The update made these key findings:

A. Chinese transplant hospitals are providing matching transplant organs within a month of patient requests. ${ }^{65}$ The organs are sourced from living donors, which means that the organs are harvested while the donors are still alive. ${ }^{66}$

B. Organs are available on demand and are sold both to domestic patients and to transplant tourists worldwide. ${ }^{67}$

C. The organ transplant infrastructure has grown rapidly since 2000, the onset of forced organ harvesting in China with Falun Gong victims. Many hospitals have built new transplant centres and new transplant wings and installed new beds in old buildings. ${ }^{68}$ As well, many Chinese hospitals have experienced significant growth in revenue, with their organ transplant departments being the main profit drivers. ${ }^{69}$

D. A calculation based on hospital bed counts, bed utilization rates, staff numbers, in conjunction with the size of grants, awards and new infrastructure in the organ transplant facilities in China showed that the actual volume and scale of organ transplants in China far exceeds the official claim of 10,000 organ transplants per year. ${ }^{70}$

\footnotetext{
${ }^{60}$ Ibid.

${ }^{61}$ Minghui Library, Statistics and Charts of Persecution from 1999-2017 (Chinese), accessed November 15, 2017, http://library.minghui.org/category/2,418,1.htm - G2.

${ }^{62}$ David Kilgour, Ethan Gutmann, and David Matas, "Bloody Harvest/The Slaughter - An Update," 18, accessed from August 26, 2016 to September 7, 2017, http://endorganpillaging.org/wp-content/uploads/2016/06/Bloody Harvest-The Slaughter-June-23-V2.pdf.

${ }^{63}$ Ibid., 11.

${ }^{64}$ Ibid., Chap. 9, accessed February 12, 2018, https://endtransplantabuse.org/an-update-chapter-nine-findings-from164-hospitals-volume-drivers/.

${ }^{65}$ Ibid., 288; Torsten Trey, "Transplant Medicine at a Crossroads," in State Organs: Transplant Abuse in China, eds. David Matas and Torsten Trey (Niagara Falls: Seraphim Editions, 2012), 20.

${ }^{66} \mathrm{Ibid} ., 383$. The quality of a transplant organ is determined by its ischemic time, which is the length of time that the organ is left without blood circulation. The shorter the ischemic time of the organ, the better is the success rate for the organ transplant. Organs lose their eligibility for transplant if they are left too long without blood circulation. As such, to optimize the quality of transplant organs, organs in China are harvested from living donors, who are either fully conscious or alive, or brain dead but with functional cardiac circulation at the time of transplant.

${ }^{67}$ Ibid., 62, 288-289.

${ }^{68}$ Ibid., 15.

${ }^{69}$ Ibid., 21.

${ }^{70}$ Ibid., 372-380.
} 
E. Forced organ harvesting is directed by the Chinese State/Communist Party machinery. It involves institutions of health, the military, the judiciary, law enforcement, the prisons, and the civil administration systems. ${ }^{71}$

For years, the official Chinese position was that the organs in China for transplantation were being sourced from executed criminals or voluntary donors. Former health minister Huang Jiefu asserted that over $90 \%$ of transplant organs were sourced from death-row criminals. ${ }^{72}$ This figure is misleading as China never officially admitted to sourcing organs from prisoners of conscience. As such, prisoners of conscience are systematically excluded from the official statistics on organ sources. Medical doctors consider the practice of sourcing organs from death-row criminals ethically untenable. ${ }^{73}$ However, ethical debates surrounding this practice ignore an important factual issue - are these organs being sourced elsewhere, from prisoners of conscience?

Since 2000, there has been a steep upward trend in organ transplant activities in China. There was an officially reported increase in annual transplant volume from about 4,000 in 1999 to over 13,000 in 2004 - an increase of more than $230 \%$ over five years. ${ }^{74}$ The number of transplant centres in China increased from approximately 150 to over 1,000, while wait times for organs dramatically decreased to one to four weeks. ${ }^{75}$ Such steep increase within five years has not been observed in other countries. According to the Global Observatory on Donation and Transplantation (GODT) which monitors the number of organ donations and transplantations globally, the annual transplant increase worldwide is about an equivalent of $10-15 \%$ in a similar five year window. ${ }^{76}$

While organ transplant volumes were increasing exponentially in China, the volume of death penalty executions was declining. The rate of execution declined even further after 2007 when China required all death sentences to be approved by the Supreme People's Court. ${ }^{77}$ Organ transplant volumes in China cannot be adequately accounted for by death-row criminals. There has to be another source of organs to explain the anomalous growth in organ transplant volumes in China. Chinese criminal law requires convicted death row prisoners to be executed within seven days of sentence. ${ }^{78}$ Chinese hospitals can only provide matching organs to patients within a short time if there is a large pool of living donors who are available for harvesting on demand. It is impossible to maintain such a pool if each living donor has to be executed within seven days. ${ }^{79}$ As well, organs from death-row criminals are often unsuited for transplantation because of the prevalence of medical conditions and infectious diseases among them. ${ }^{80}$

In 2014, China announced that it would stop procuring organs for transplantation from executed prisoners and would instead rely on voluntary donations. The announcement has not been implemented in legislation and the 1984 law which permits organ sourcing from executed prisoners without consent of either the prisoners or their families has not been revoked. ${ }^{81}$

${ }^{71}$ Ibid., 411-415; Allison et al., "Historical Development and Current Status of Organ Procurement from Death Row Prisoners in China," BMC Medical Ethics 16, no. 85 (2015), 2, accessed February 10, 2017, https://bmcmedethics. biomedcentral.com/articles/10.1186/s12910-015-0074-0

${ }^{72}$ Jiefu Huang, Yilei Mao, and J Michael Millis, “Government Policy and Organ Transplantation in China," The Lancet 372, Issue 9654, no. 612 (2008), 1937, accessed February 10, 2017, doi:10.1016/S0140-6736(08)61359-8.

${ }^{73}$ Paul et al., "Human Rights Violations in Organ Procurement Practice in China," BMC Medical Ethics 18, no.11 (2017), 2-3, accessed March 20, 2017, doi:10.1186/s12910-017-0169-x.

${ }^{74}$ Huang et al., Government Policy and Organ Transplantation 1938.

75 Torsten Trey, Transplant Medicine at a Crossroads, 20. Figure updated in Kilgour, et al, Bloody Harvest/The Slaughter, 17.

${ }^{76}$ Torsten Trey and David Matas, "State-organized Criminal Forced Organ Harvesting," Journal of Trafficking and Human Exploitation 1, no. 2 (2017), 182.

${ }^{77}$ David Matas, "Numbers," in State Organs: Transplant Abuse in China, ed. David Matas and Torsten Trey (Niagara Falls: Seraphim Editions, 2012), 8384.

${ }^{78}$ The Congressional-Executive Commission on China, Criminal Procedure Law of the People's Republic of China, People's Republic of China Legal Provision (Amended March 14, 2012), article 251, accessed February 12, 2017, http://www.cecc.gov/resources/legal-provisions/criminal-procedure-law-of-the-peoples-republic-of-china.

${ }^{79}$ Trey and Matas, State-organized Criminal Forced Organ Harvesting, 180.

${ }^{80}$ Kilgour et al., Bloody Harvest/The Slaughter, 401.

${ }^{81}$ Allison et al., Historical Development and Current Status, 3. 
Academic studies have found that the recent organ donation program in China has produced a cadaveric organ donation rate which is one of the lowest in the world. ${ }^{82}$

In December 2017, the Xinhua news agency proclaimed that voluntary organ donation volumes in 2016 had increased by 50\% from 2015, with more than 330,000 registered organ donors and over 38,000 donations of major organs. ${ }^{83}$ The integrity of these figures is questionable. Exactly 25,000 registered donors were found added to the Chinese organ donation registry in a single day. ${ }^{84}$ This sudden large increase in a country which traditionally has been reluctant to donate organs is implausible. The increase in donations by a simple large number suggests data manipulation. Even if the claim were true, it could not account for anywhere near the actual volume of organ transplants in China. The official Government of China transplant volume figures are easily surpassed by the volume transplants performed by a few large hospitals in China. ${ }^{85}$ Moreover, the organs of those near death in hospital would be available only for those on transplant waiting lists. For those who book transplants in advance, organ sources would have to be determined in advance and, for vital organs, booked in advance for killing.

The conclusion of research and investigation conducted starting from 2006 was that organs for transplantation from those booked for killing in advance were primarily sourced from Falun Gong practitioners ${ }^{86}$ with a minority sourced from other prisoners of conscience-Tibetans, Uighurs and House Christians ${ }^{87}$ This conclusion was affirmed in $2016^{88}$ as organs from officially undisclosed sources continued to flood the Chinese transplant market, and reports of Falun Gong practitioners and other prisoners of conscience being systematically forced to take blood tests persisted. ${ }^{89}$ The large population of detained Falun Gong prisoners of conscience provides a cogent and ready explanation for the source of the large volume of harvested organs. Falun Gong practitioners and other prisoners of conscience were systematically subject to costly medical examinations and blood tests while criminal detainees, other than those sentenced to death, were excluded from such procedures. ${ }^{90}$ Falun Gong practitioners suffered forced labour, torture and deaths from injury and lack of medical treatment. These costly medical examinations could not have been administered for the sake of Falun Gong practitioners' health. Rather, the medical examinations were necessary to assess their organ health for the purpose of transplant, for screening and matching. ${ }^{11}$

Since the advent of the eradication campaign against Falun Gong, the Chinese Government has made the development of China's organ transplant infrastructure an important element in its Five Year Plans. ${ }^{92}$ The military and the central and local governments have invested heavily in domestic medical institutions to carry out basic research and development in organ transplantation

\footnotetext{
${ }^{82} \mathrm{Ni}$ An, Yuanyuan Shi, Yabo Jiang, and Linlin Zhao, "Organ Donation in China: The Major Progress and the Continuing Problem," The Journal of Biomedical Research 30, no. 2, 2016, 81, accessed August 20, 2017, doi: 10.7555/JBR.30.20150160.

${ }^{83}$ Xinhua Daily News, "What's Behind the Organ Donation in China Being Second in the World," Xhinhua Daily News, December 1, 2017, accessed February 10, 2018, http://www.xinhuanet.com/2017-12/01/c 1122039703.htm.

${ }^{84}$ Trey and Matas, State-organized Criminal Forced Organ Harvesting, 185; Doctors Against Forced Organ Harvesting, "Unusual Course of Organ Donation Registry Numbers in China," January 15, 2017, accessed August 30, 2017, https://dafoh.org/wp-content/uploads/Registered-organ-donors-in-China-2015-2016.jpg.

${ }^{85}$ Kilgour et al., Bloody Harvest/The Slaughter, 15.

${ }^{86}$ Ibid., 428.

${ }^{87}$ Ibid; Gutmann, The Slaughter, 27.

${ }^{88}$ Kilgour, et al., Bloody Harvest/ The Slaughter, 316.

${ }^{89}$ For instance, according to a report by Minghui in April 2014, Chinese police were forcibly taking blood samples from Falun Gong practitioners in their own homes. Source: Liaoning, "Police from Multiple Areas Force Blood Tests on Falun Gong Practitioners at Their Homes," July 5, 2014, accessed December 2, 2017, https://www. minghui.org/mh/articles/2014/7/5/多地警察上门逼迫法轮功学员验血-294315.html.

${ }^{90}$ Matas and Kilgour, Bloody Harvest, 50.

${ }^{91}$ Doctors Against Forced Organ Harvesting, "Implausible Medical Examinations of Falun Gong Forced Labor Camp Workers in China," DAFOH, August 10, 2014, accessed January 30, 2017, http://www.dafoh.org/ articlesandreports/implausiblemedicalexaminationsfalungongforcedlaborcampworkers/

${ }^{92}$ Kilgour et al., Bloody Harvest/ The Slaughter, 353.
} 
and to promote its industrialization. ${ }^{93}$ It is apparent that forced organ harvesting of Falun Gong practitioners in China is not just tolerated by the Chinese regime; it is organized and operated by the State. ${ }^{94}$

The findings of state organized forced organ harvesting in China are based in part on circumstantial evidence. The limited eyewitness evidence is the consequence of lack of transparency in China's organ transplant system. This lack of transparency is itself an indicator of wrongdoing. The suppression of information in this area is consistent with overall pattern of cover-up. This cover-up is a defining feature of the cold genocide against Falun Gong.

\section{The Intent to Destroy Falun Gong}

The Convention on the Prevention and Punishment of the Crime of Genocide requires perpetrators to have a specific intent to destroy a national, ethnical, racial or religious group, in whole or in part. ${ }^{95}$ This specific intent can be express or implied. In the eradication campaign against Falun Gong, the Chinese Communist regime demonstrates both an express and implied intention to destroy Falun Gong in whole or in part.

\section{Express Intention}

On November 30, 1999, Li Lanqing, under the Jiang's directions, announced to 3,000 fellow CCP officials at the Great Hall of Beijing a policy against Falun Gong to "defame their reputations, bankrupt them financially and destroy them physically." ${ }^{\prime 96}$ This unequivocal call constitutes an express intention to destroy Falun Gong in whole or in part. In February 2001, Jiang convened a "central work conference" in which he called on Party officials to "unify their thinking and redouble their efforts to eliminate Falun Gong." ${ }^{\prime 97}$ In the Tenth Five-Year Plan, the elimination of Falun Gong was designated as a national priority. ${ }^{98}$

Statements of intent to destroy Falun Gong are legion in official documents issued at the municipal and lower levels throughout the decades to the present, especially during times which the regime considers sensitive. The World Organization to Investigate the Persecution of Falun Gong (WOIPFG) documented the regime's fifteen years of battle to transform the Falun Gong from 1999 to 2014. In particular, the NGO highlighted directives which call for "Educational Transformation Decisive Battle" (教育转化决战 Jiàoyù zhuănhuà juézhàn), issued at various levels of government in many provinces such as Hubei, Hunan, Gangsu, Anhui, Sizhuan, Shandong, Shanghai and Guangdong. ${ }^{99}$ Noakes and Ford reported similar documents which call for "comprehensive clean-up" and efforts to "dispose" of Falun Gong. ${ }^{100}$ By cross-referencing such documents from geographically disparate regions, the authors identified these directives as part of several nationally coordinated anti-Falun Gong initiatives. ${ }^{101}$ However, these directives are seldom publicly announced at the national level.

\footnotetext{
${ }^{93}$ Ibid., 354.

${ }^{94}$ Trey and Matas, State-organized Criminal Forced Organ Harvesting, 184.

${ }^{95}$ United Nations Office of the Special Adviser for the Prevention of Genocide and the Responsibility to Protect, "Definitions: Genocide," accessed November 30, 2017, http://www.un.org/en/genocideprevention/genocide. $\underline{\text { html. }}$.

${ }^{96}$ Matas and Kilgour, Bloody Harvest, 222. Source of this information is an interview with Li Baigen who attended the November 30, 1999 meeting. He was then assistant director of the Beijing Municipal office. He is now resident in the United States. The U.S. Department of State Country Report for China for 1999 refers to the meeting.

${ }^{97}$ Noakes and Ford, Managing Political Opposition Groups, 662.

${ }^{98}$ Ibid.

${ }^{99}$ World Organization to Investigate the Persecution of Falun Gong, Investigative Report on the Chinese Communist Regime's "Educational Transformation Decisive Battle" Policy of the Persecution of Falun Gong, August 11, 2014, accessed November, 2017, https://www.zhuichaguoji.org/node/43884\# Toc394744064.

${ }^{100}$ Noakes and Ford, Managing Political Opposition Groups, 663 (footnote 29).

${ }^{101}$ Ibid., 659.
} 
Inferred Intention

According to the jurisprudence of the international criminal tribunals, intent to destroy a group in whole or in part could be inferred from such factors as the scale and the nature of the atrocities committed, the number of group members affected, the use of derogatory language towards members of the targeted group, the systematic targeting of victims on account of their membership planning. ${ }^{102}$ Virtually all of these factors are satisfied in the eradication campaign against Falun Gong.

The scale and severity of torture applied to Falun Gong practitioners under the direction of the 610 Office, and the verified cases of death resulting from torture evinces an intention not just to harm but to destroy Falun Gong. The campaign against Falun Gong is conducted using status apparatus through a chain of command which connects the primary perpetrators to the highest echelons of Party leadership. In the capacity of President and head of Chinese Communist Party in 1999, Jiang Zemin directed, controlled, supervised, authorized and condoned the eradication campaign against Falun Gong. The provincial party and state officials, under the unified direction of the 610 Office, oversaw law enforcement and prison management, the operation of detention facilities and labor camps, and actions of the police and prison officials. ${ }^{103}$

The intent to destroy Falun Gong can also be inferred from state involvement in the forced organ harvesting industry. Forced organ harvesting in China is not a private enterprise. It is spearheaded by the Chinese Communist Party/State. ${ }^{104}$ The campaign is implemented by the Ministry of Health, and later by its successor, the National Health and Family Planning Commission. ${ }^{105}$ Transplant organs are procured through a chain of command involving both military and civilian institutions, facilitated by the 610 Office. ${ }^{106}$ In this chain of command, the People's Liberation Army General Logistics Department functions as the core operations unit responsible for allocation, distribution, transportation, delivery, security and accounting of transplant organs. ${ }^{107}$ With cooperation from other military units, armed police, the Party Political and Legal Affairs Committee, the health system and organ brokers, transplant centres of military and civilian hospitals gain access to prison and detention centres to procure organs. ${ }^{108}$

No one survives the removal of his/her vital organs - heart, lungs, liver or both kidneys. The Chinese Communist regime's selective targeting of Falun Gong practitioners for forced organ harvesting on an industrial scale evinces an intention to kill Falun Gong practitioners in large numbers. This is an intention to destroy Falun Gong in whole or in part.

The Option of Renouncing Falun Gong

Before they were tortured or killed, Falun Gong adherents were given the option of renouncing the practice of Falun Gong. As the scope of the Genocide Convention is limited to physical destruction, ${ }^{109}$ there is an argument that the mental element of genocide is not satisfied. The masterminds and architects behind the eradication campaign intended more the eradication of the spiritual faith and less the physical destruction of Falun Gong adherents per se.

The regime resorted to increasingly grave measures such as killings and severe torture only after Falun Gong adherents resisted its attempts to convert. If all Falun Gong adherents willingly renounced Falun Gong, the eradication campaign might have conceivably ended without any violence or bloodshed. Some scholars take the position that destroying a religious group without physically destroying the people within the group does not constitute genocide. ${ }^{110}$

\footnotetext{
${ }^{102}$ The Prosecutor v. Jean-Paul Akayesu, Trial Chamber Judgement, September 2, 1998, ICTR-96-4-T, para. 523- 524.

${ }^{103}$ Matas and Cheung, Concepts and Precepts, 68.

${ }^{104}$ Kilgour et al., Bloody Harvest/ The Slaughter, 408.

${ }^{105}$ Ibid.

${ }^{106}$ Ibid.

${ }^{107}$ Ibid., 331, 398, 408.

108 Ibid., 412-413.

${ }^{109}$ United Nations Office of the Special Adviser for the Prevention of Genocide and the Responsibility to Protect, Definitions: Genocide.

${ }^{110}$ William A. Schabas, Genocide in International Law: The Crime of Crimes, 2nd ed. (New York: Cambridge University
} 
This restrictive interpretation of intention does not comport with the text and purpose of the Genocide Convention. On a plain reading of Article II of the Convention, there is no indication that the intention to destroy must be an intention to destroy physically the members of the target group. This restrictive interpretation is repugnant to the object and purpose of the Convention, which is to safeguard the existence of human groups, and to enshrine the most elementary principles of humanity. ${ }^{111}$ A person's right to choose a religious belief without violent interference and coercion is an elementary principle of humanity. ${ }^{112}$ The restrictive interpretation limits the scope of religious freedom and spiritual faith.

The restrictive interpretation is also inconsistent with the travaux preparatoires (preparatory works) of the Convention. The inclusion of religious groups as protected groups indicates an intention to protect religious beliefs. ${ }^{113}$ A religion can always be renounced. To preclude a finding of genocidal intention where the victims were given an option to renounce denies the very protection that the Genocide Convention intended to confer on religious groups.

\section{The Cold Genocide Against Falun Gong}

Although the case of Falun Gong satisfies the component of the classical definition of genocide which refers to physical destruction, this definition places an undue emphasis on the physical aspect of the genocide and fails to capture the campaign against Falun Gong in all of its sophisticated and multifaceted dimensions. Recent genocide scholarship on cold genocide encourages a deeper inquiry into the significance of various acts of transgression committed against Falun Gong. In contrast with a hot genocide which highlights the immediate unleashing of violent death, a cold genocide recognizes subtler forms of structural violence which eventually lead to the annihilation of the targeted group. Acts such as ideological conversion, propaganda and demonization are not independent from the physical genocide, but part of the same project to annihilate Falun Gong, aiming for a thorough elimination of the practice and its practitioners.

The theory of cold genocide is still nascent. The precise scope and meaning of the concept is still open-ended and indeterminate. Nonetheless, we can conclude from existing literature on the topic at least two elements which distinguish a cold genocide. First, a cold genocide is multidimensional, in the sense that campaigns aim at the destruction of the victims in many different ways. ${ }^{114}$ Second, it is harder for outsiders to notice. Its lesser visibility facilitates prolonged duration. ${ }^{115}$ The society in which a cold genocide takes place often normalizes the genocide. In past Chinese Communist regime eradication campaigns, the perpetrators expended extensive effort to normalize their acts of cruelty by inculcating the Chinese populace with philosophies of violence against the designated enemies of the state or counterrevolutionaries. ${ }^{116}$ These techniques of normalization are similarly observed in the present day genocide of Falun Gong.

In the following analysis, we contend that the genocide of Falun Gong can be identified as a cold genocide on the basis that it is multidimensional, subtle and normalized. These factors not only distinguish Falun Gong as a cold genocide; they also explain why the campaign against Falun Gong is underrepresented in genocide studies. In the final section of the analysis, we address potential weaknesses and limitations in our thesis that the eradication campaign against Falun Gong constitutes a cold genocide.

Press, 2009), 82.

${ }^{111}$ Reservations to the Convention on the Prevention and Punishment of the Crime of Genocide, Advisory Opinion of 28 May 1951, International Court of Justice, 15, 7.

${ }^{112}$ United Nations General Assembly, International Covenant on Civil and Political Rights, December 16, 1966, article 18(1)-(2); Nathan Lee, "Convert or Die: Forced Religious Conversions and the Convention on the Prevention and Punishment of the Crime of Genocide," Georgetown Journal of International Law 47, no. 2 (2016), 584.

${ }^{113}$ Lee, Convert or Die, 591.

${ }^{114}$ Anderson, Colonialism and Cold Genocide, 10.

${ }^{115}$ Ibid., 12.

${ }^{116}$ Yuan-Horng Chu, "The Counterrevolution-A Family of Crimes: Chinese Communist Revolutionary Rhetoric, 1929-89," in The Web of Violence: From Personal to Global, eds. Jennifer Turpin and Lester R. Kurtz (Chicago: University of Illinois Press, 1997), 69. 
Multidimensional Destruction

A cold genocide is a sophisticated phenomenon. The perpetrator, in addition to some physical destruction, seeks to eradicate the victim group through non-physical means. ${ }^{117}$ Anderson argued that, in non-physical forms of genocide, physical destruction of the victims may not be intended. Rather, oppressive acts or policies are calculated to bring about the eventual destruction of the group by undermining the group's foundations of existence. ${ }^{118}$ In particular, Anderson identified destruction with attacks on three group dimensions-cultural, economic and political sustainability. ${ }^{119}$ Anderson was using West Papua, and not China, as a case study. Nonetheless, his three specific dimensions of attack are the same as the three dimensions of the Communist Chinese Party's attack against Falun Gong - defaming their reputations, bankrupting them financially and destroying them physically. ${ }^{120}$

Pursuant to their policy, the Chinese communist regime not only has destroyed Falun Gong practitioners physically through torture and forced organ harvesting. Policies and systems have been established to attempt, through brainwashing and reeducation centers, to separate Falun Gong practitioners from their spiritual beliefs, to accept Party ideology and to reject the Falun Gong community. These campaigns and policies have undermined Falun Gong practitioners' conditions of life and severed them from their spiritual identity. Falun Gong practitioners, once identified at their work place, lose their jobs and income. These measures further the destruction of Falun Gong in incremental steps. The Chinese communist regime has also sought to ruin the reputation of Falun Gong and the social life of the practitioners both in China and abroad. Awareness of the Party's multidimensional destruction effort is critical to understanding the genocide of Falun Gong because that genocide is the interaction between multiple, incremental measures. This multidimensional incremental effort may not be obvious to a casual observer, but is destructive and lasting in its result.

\section{Spiritual Death}

Foremost in the multidimensional destruction of Falun Gong is the eradication of spiritual belief by forcing Falun Gong practitioners into ideological conversion. Forced ideological conversion is similar to forced assimilation, ethnocide or cultural genocide. In all of these cases, the victim group is forced to abandon its way of life and identity. These measures are designed to ensure the eventual disappearance of the victim group.

Systematic forced ideological conversion has been particularly important in the effort to eradicate Falun Gong. Since the onset of the eradication campaign in July 1999, detained Falun Gong practitioners were offered freedom in exchange for signing a confession and renouncing their beliefs and practice of Falun Gong. ${ }^{121}$ Those who resisted were subjected to torture, death through torture and forced organ harvesting. Falun Gong practitioners faced the cruel choice between soul and body, the choice either to abandon their spiritual existence and identity or to abandon their health and lives, to die spiritually or to die physically. ${ }^{122}$ Either choice was to become part of the gradual extinction of Falun Gong.

Brainwashing or reeducation is a form of psychological torture. The goal of brainwashing is forced conversion from a freely embraced spiritual belief to acceptance of content imposed by the Party/State. Brainwashing takes place in forced labour camps and other detention facilities. Falun

\footnotetext{
${ }^{117}$ Anderson, Colonialism and Cold Genocide, 10.

${ }^{118}$ Ibid.

${ }^{119}$ Ibid.

${ }^{120}$ Matas and Kilgour, Bloody Harvest, 23.

${ }^{121}$ Gutmann, The Slaughter, 141-142. Also, the Falun Gong in China: Review and Update - Hearing before the CongressionalExecutive Commission on China, 112 ${ }^{\text {th }}$ Cong., 2nd Session, 4, 6 (2012), accessed February 12, 2017, http://www.cecc.gov/sites/chinacommission.house.gov/files/documents/hearings/2012/CECC Hearing - Falun Gong in China Review and Update - 12.18.12.pdf.

${ }^{122}$ Torsten Trey, "Unprecedented Evil behind Forced Organ Harvesting: The Choice to Die Spiritually or Physically," in An Unprecedented Evil Persecution: A Genocide Against Goodness in Humankind, eds. Torsten Trey and Theresa Chu, (USA: Clear Insight Publishing, 2016), 126.
} 
Gong practitioners are taken to reeducation confinement and are forcibly exposed to long hours of anti-Falun Gong propaganda films and literature which defames and demonizes Falun Gong. They are bombarded by these messages to the point of physical exhaustion and mental breakdown, with the intent and often the effect of recanting their beliefs. ${ }^{123}$

The Chinese Communist regime labelled its forced conversion process as Zhuan Hua (转化 or Transformation). The 610 Office specified five standards the transformation process had to meet. Falun Gong adherents had to:

1. Relinquish the practice;

2. Write a repentance statement;

3. Surrender all Falun Gong books and materials;

4. Write testimonials against Falun Gong and its founder; and

5. Assist in the transformation of other Falun Gong practitioners.

These standards have been adopted throughout the country. ${ }^{124}$ The intended outcome of this transformation campaign is the eradication of the practice amongst the living and the death of those not transformed. Quotas for forced conversion are issued to local authorities who are incentivized to use any means necessary to achieve these targets, including coercive tactics such as forcedfeeding, sleep deprivation, and shocks with electric truncheons. ${ }^{125}$

The transformation work against Falun Gong adherents is not just carried out by state officials in detention facilities; it has become a national activity involving all elements of the Party/State and its cooperating agents. This is clear from the dozens of official documents circulated as part of the "2010-2012 Transformation through Reeducation Assault and Consolidation Overall Battle Work Plan". ${ }^{126}$ These documents enlist local authorities, Party organizations, businesses, and individuals in the transformation of Falun Gong adherents. For instance, an April 6, 2010 Jiyuan Municipal Bureau of Industry and Information Technology document called on its local 610 Office to sign "responsibility agreements" with businesses and to inspect regularly the "transformation" work of those businesses. ${ }^{127}$ A May 5, 2010 document issued by Tianwen Town People's Government, required organizations and small groups to conduct an "educational assault" on the homes of Falun Gong adherents. ${ }^{128} \mathrm{~A}$ document issued in June 13, 2010 by the Jiangxi Provincial Reeducation Through Labour Administration Bureau called for the People's Police to "improve their knowledge and studies of sociology, medicine, psychology, and religion as part of their 'transformation through reeducation' work." 129

\section{Social Death}

Claudia Card wrote, "loss of social vitality is loss of identity and thereby of meaning for one's existence." ${ }^{130}$ She argues that social death is central to an understanding of the evil of genocide. ${ }^{131}$ The Chinese Party/State makes a great effort to destroy the social existence of Falun Gong practitioners. By systematic propaganda, dehumanization and demonization, Falun Gong practitioners and society become poles apart. Falun Gong practitioners face rejection and condemnation from their communities. They are confronted with hate, isolation, and surveillance in their living and work environment, and ostracized or excommunicated from their families,

\footnotetext{
${ }^{123}$ Yiyang Xia, "Brainwashing: Extermination of Mind and Body," in An Unprecedented Evil Persecution: A Genocide Against Goodness in Humankind, eds. Torsten Trey and Theresa Chu, (USA: Clear Insight Publishing, 2016$), 85$. ${ }^{124}$ Ibid., 81-82.

${ }^{125}$ Noakes and Ford, Managing Political Opposition Groups in China, 665

${ }^{126}$ The Congressional-Executive Commission on China, Communist Party Calls for Increased Efforts to "Transform" Falun Gong Practitioners as Part of Three-Year Campaign, Commission Analysis (March 22, 2011), accessed December 2, 2017, https://www.cecc.gov/publications/commission-analysis/communist-party-callsfor-increased-efforts-to-transform-falun-gong.

${ }^{127}$ Ibid.

${ }^{128}$ Ibid.

${ }^{129}$ Ibid.

${ }^{130}$ Claudia Card, “Genocide and Social Death,” Hypatia 18, no.1 (2003), 63.

${ }^{131}$ Ibid.
} 
friends and social circles. Social death and spiritual death, unlike physical massacre, are silent and bloodless, but they achieve a similar, but profound effect of eradication.

The 610 Office conducted an extensive demonization campaign to incite hatred against Falun Gong. ${ }^{132}$ This attempt at incitement has proven more difficult than expected. Due to Falun Gong's practice of kindness in Chinese society during the seven years after its introduction, Falun Gong was highly regarded in China; the Chinese generally were aware that Falun Gong practitioners are good people. The 610 Office reacted through escalation. They staged a self-immolation incident to demonize Falun Gong. In 2001, the regime organized five people to pretend to set themselves on fire at Tiananmen Square before an official state video, and had them claim to be Falun Gong practitioners. ${ }^{133}$ The video of self-immolation was broadcasted in major state-sponsored media nationwide to discredit Falun Gong, and portray Falun Gong as dangerous. An analysis of the video showed that the apparent self-immolators were actors, not Falun Gong practitioners, and the incident was staged. ${ }^{134}$ Without independent news to expose this fabrication, the self-immolation incident turned public opinion in China against Falun Gong.

Many Chinese citizens were led to support the regime in its surveillance of Falun Gong practitioners. Party-sponsored grassroots organizations, such as resident associations, are co-opted as Party agents to exert pressure on Falun Gong practitioners in local communities. These agents report to the Public Security Bureau who came to arrest and detain Falun Gong practitioners. Neighbourhood committees are also mobilized by the 610 Office to have regular patrols and to take down Falun Gong messages posted in the neighbourhood. ${ }^{135}$ The pressure from these grassroots agents isolated Falun Gong practitioners from their own communities. The objective of this initiative, as vividly described in a CCP municipal office issued document, is to "render Falun Gong practitioners like rats running across the street that everyone shouts to smash; don't leave them any space" ${ }^{136}$

Last but not least, the 610 Office established a collective penalty system to create further polarization between Falun Gong practitioners and the rest of the society. Under this system, work units or private employers of Falun Gong practitioners are penalized if the Falun Gong practitioner is caught protesting at Tiananmen Square. ${ }^{137}$ Financial punishments are imposed on local officials, such as village security heads, if inspection teams discover Falun Gong literature in the geographical area for which they are responsible. ${ }^{138}$ The collective penalty system is supplemented by a system of incentives and rewards to those who report on Falun Gong activities and Falun Gong practitioners' underground printing sites. ${ }^{139}$ This collective penalty and reward system turned Falun Gong practitioners' colleagues, friends and confidantes into their enemies. Financial bankruptcy and economic ruin is another method the Party has used to undermine Falun Gong practitioners' conditions of life, and destroys their social vitality. Falun Gong practitioners are systematically denied access to jobs or further education. ${ }^{140}$ Many of them are driven to unemployment and

\footnotetext{
132“A State Crime," Stop Organ Harvesting in China, accessed February 20, 2018, http://www.stoporganharvesting. org/a-state-crime/; Noakes and Ford, Managing Political Opposition Groups in China, 665-666.

${ }^{133}$ Cheung, The Intersection between Mindfulness and Human Rights, 60; He Yu, "Former 610 Office Head Li Dongsheng Indicted," Clearwisdom, August 29, 2015, accessed February 10, 2017, http://en.minghui.org/html/ articles/2015/8/29/152297.html

${ }^{134}$ Gutmann, The Slaughter, 167. The International Education Development, a USbased NGO linked to the United Nations issued a public statement verifying that the 2001 selfimmolation was a fabrication. Source: En Tang, "Twelve Years after the Tiananmen Self-immolation Hoax, More and More People Understand the Truth," Clearwisdom, March 7, 2013, accessed February 10, 2017, http://en.minghui.org/html/articles/2013/3/7/138396. html.

${ }^{135}$ Noakes and Ford, Managing Political Opposition Groups, 666.

${ }^{136}$ Ibid.

${ }^{137}$ David Matas and David Kilgour, Report Into Allegations of Organ Harvesting of Falun Gong Practitioners in China, July 6, 2006, Appendix 9, accessed September 3, 2017, http://organharvestinvestigation.net/report0607/ report060706-eng.pdf.

${ }^{138}$ Noakes and Ford, Managing Political Opposition Groups, 667.

${ }^{139}$ Ibid., 666-667.

${ }^{140}$ Ibid., 672.
} 
their pensions are withdrawn. ${ }^{141}$ Their financial hardship is compounded by the regular fines and confiscation of personal property by the regime. As a result, many Falun Gong practitioners are homeless and destitute.

Social isolation by itself may not justifiably be called cold genocide. As part of a multifaceted campaign, this isolation contributes to genocide.

\section{Subtlety and Invisibility}

Slow motion genocide is a blind spot in classical genocide studies. ${ }^{142}$ The diffusion of impact across space and time makes it harder for observers to appreciate the full destructive potential of these genocides. ${ }^{143}$ It is not only the slow motion of a genocide which makes it elusive. Instead, more generally what distinguishes a cold genocide is its subtlety. A cold genocide is subtle in terms of visibility because, in addition to being slow, it is also covered up and its victims are marginalized from society in a way that denies their mainstream attention.

In the case of Falun Gong, we observe these three phenomena which have led to the subtlety of the genocide. First, slowness. The genocide began in 1999; it has stretched over eighteen years and continues today. As we wrote earlier, genocides which have captured international attention usually last no longer than five to ten years. A genocide which lasts longer than ten years is rare. As such, the genocide against Falun Gong, because of its slowness, stands as an anomalous case of genocide.

The perpetrators' systematic cover-up reinforces the lack of visibility, the minimal level of conscious perception of the genocide. The manipulation of media by the Chinese Party/State to disseminate propaganda and misinformation has become an effective tool not only to incite hatred, but also to cover up and deny their act of genocide against Falun Gong. A significant aspect of the regime's cover-up is the distortion and deletion of publicly available data. This sort of cover-up is particularly noticeable with transplantation data. Transplant hospitals, media, and official websites regularly remove information that may implicate them in the crime of forced organ harvesting, killing innocents for their organs. For instance, after the publication of Matas-Kilgour report in 2006, the transplant registry located in Hong Kong which used to be open to the public denied public access to their online statistics on organ transplant volumes. The numbers on transplant volumes were artificially decreased to a low, non-alarming figure which was incongruent with the transplant centers' scale and staff size. ${ }^{144}$ While the transplant infrastructure in China expanded over ten years, the officially reported transplant numbers did not show any growth and remained implausibly at around 10,000 per year for the ten years between 2006 and 2016. Data manipulation on Chinese websites was discovered with the help of archived information, as documented in the 2016 update by Kilgour, Gutmann and Matas. ${ }^{145}$

Another form of cover-up is the regime's online censorship of search terms related to Falun Gong. Several investigations of internet censorship have shown that Falun Gong is the most censored topic in China. In June 2009, the regime developed a censorship/spyware system known as "Green Dam Youth Escort" which was to be installed on all Chinese personal computers. Researchers at the University of Michigan found two lists of censored keywords on this system, the longer of which was called Falunwords.lib, with $90 \%$ of the 6500 words related to Falun Gong. ${ }^{146}$

\footnotetext{
${ }^{141}$ Minghui Correspondent in China, “The Economic Persecution of Falun Gong Practitioners in Beijing" Clearwisdom, March 23, 2004, accessed December 2, 2017, http://www.en.minghui.org/html/ articles/2014/3/23/146039p.html.

${ }^{142}$ Anderson, Colonialism and Cold Genocide, 9.

${ }^{143}$ Ibid., 12.

${ }^{144}$ Kilgour et al., Bloody Harvest/The Slaughter, Chapter 8.

${ }^{145}$ Ibid., 265.

${ }^{146}$ Jan Jekielek, "Google Exit Highlights China's Most Censored Internet Topic: Falun Gong," The Epoch Times, March 26, 2010, accessed November 30, 2017, https://www.theepochtimes.com/hlights-chinas-most-censoredinternet-topic-falun-gong 1515779.html. This report corroborated with the study findings published by Jedidiah R. Crandall, et al., "Chat Program Censorship and Surveillance in China: Tracking TOM-Skype and Sina UC," First Monday: Peer-reviewed Journal on the Internet 18, no. 7 (2013), n.p., accessed November 26, 2017, http://firstmonday.org/ojs/index.php/fm/article/viewArticle/4628/3727.
} 
Hackers who have procured lists of censored key words have found that Falun Gong is the most censored subject on the Chinese popular chat client $\mathrm{QQ}^{147}$ and on other Chinese websites. ${ }^{148}$

A cold genocide is also subtle because of the marginalized status of the victim group. Riccardo, Marczak, and Diamadis point out that the presence of bias or discrimination against the victims is an important factor which leads to their suffering being overlooked. ${ }^{149}$ The cause and nature of bias against different victim group will differ, but the effect is the same-to marginalize the victim group and shroud their genocide from public view and attention. The Chinese communist regime's demonization of Falun Gong and misinformation campaign against Falun Gong instills widespread bias and discrimination against Falun Gong practitioners and marginalizes them both in China and abroad. ${ }^{150}$ The misinformation has been exported to the mainstream and ethnic Chinese media outside China. ${ }^{151}$

Media and academia in the West have also played an instrumental role in marginalizing Falun Gong practitioners in the international community. To achieve an appearance of neutrality, the dominant academic and media discourse on Falun Gong took narratives from both the Chinese Communist Party and Falun Gong. ${ }^{152}$ This polarizing discourse created confusion and made it difficult for the public to appreciate the reality of the genocide and to take a decisive stance against it. The media and academia's reproduction of Chinese Communist Party's rhetoric also created suspicion in international communities towards Falun Gong. The sum effect of their work was to marginalize Falun Gong, to generate silence and denial towards the genocide, and consequently to leave Falun Gong practitioners to fend for themselves over the last eighteen years.

To put the effort of media manipulation into context and to understand its purpose, we observe that an informed society which rejected ostracism of the victim group could have arguably prevented the genocide from occurring. Prolonged misinformation undermines public opposition to an ongoing genocide, thereby creating an environment where a cold genocide can be sustained. The subtlety of a cold genocide may be necessary to maintain order and political legitimacy. A hot genocide, with its visibility, intensity and impact, can plunge a society into chaos. In the case of China, a hot genocide could have brought the Chinese regime into disrepute. By ensuring the silent disappearance of victims in the catacombs of detention centres and operation tables, the Chinese slow genocide of Falun Gong could be concealed, erased from official history and collective memory. ${ }^{153}$

\section{Normalization}

In cold genocides, the atrocities against the victim group are normalized. Normalization means weaving genocide into the fabric of society. Normalization comes from hegemony, a mode of political domination through ideology rather than force. ${ }^{154}$ The Chinese communist regime has used political hegemony to achieve normalization of its genocide against Falun Gong. Subtle yet pervasive dissemination of the perpetrator's perspectives have led the Chinese citizenry to internalize these perspectives. The citizenry have become programmed to accept the extraordinary

\footnotetext{
${ }^{147}$ The list was located by Chinese hackers in 2004, with 20\% of the search terms related to Falun Gong. Crandall, et al., Chat Program Censorship.

${ }^{148}$ In 2006, the Washington Post produced a list of censored keywords used by Chinese blog service. Of the 236 keywords, 14\% were related to Falun Gong-a proportion that is higher than any other subject. Source: "The Great Firewall of China: Keywords Used to Filter Web Content," Washington Post, February 18, 2006, accessed November 30, 2017, http://www.washingtonpost.com/wp-dyn/content/article/2006/02/18/AR2006021800554. html.

${ }^{149}$ Riccardo Armillei, Nikki Marczak, and Panayiotis Diamadis, "Forgotten and Concealed: The Emblematic Cases of the Assyrian and Romani Genocides," Genocide Studies and Prevention: An International Journal 10, no. 2 (2016), 100, accessed December 12, 2016, doi:10.5038/1911-9933.10.2.1404.

${ }^{150}$ Matas and Cheung, Concepts and Precepts, 71, 75.

${ }^{151}$ Ibid., 72.

${ }^{152}$ Ibid.

${ }^{153}$ Armillei et al., Forgotten and Concealed, 98.

154 Thomas R. Bates, “Gramsci and The Theory of Hegemony," Journal of the History of Ideas 36, no. 2 (1975), 352, accessed September 8, 2017, https://ondercetin.files.wordpress.com/2011/04/bates-1975.pdf.
} 
injustice against the Falun Gong as a normal fact. Sophisticated thought reform has subdued and co-opted what would otherwise have been dissenting voices opposing the genocide, and ensured the sustainability and long-term success of the anti-Falun Gong campaign.

A focus on normalization requires revisiting the concept of multidimensional destruction. Similar to demonization and reputational ruin, normalizing genocide also requires propaganda and ideological work on the populace. However, there are important distinctions between the two ideas, between demonization of a target population and normalizing genocide of that population. First, demonization is often achieved through direct and explicit propaganda in the media. In contrast, normalization is a more complicated and multi-leveled phenomenon where the message is "subtly disseminated at many levels of a cultural totality - at the levels of politics, education, entertainment, and common sense." 155 Second, demonization often takes the form of an ideological belief which can be consciously articulated and contested. With normalization, thoughts and beliefs are so deeply ingrained in the subconscious that they are taken for granted and accepted as common sense. ${ }^{156}$ For these reasons, normalization is a more thorough and sophisticated form of thought reform than demonization. The result of normalization is inattention; it creates an environment in which a cold genocide can thrive and achieve eradication over time.

We can see the fleshing out of normalization in the genocide against Falun Gong. The 610 Office, with its extensive reach and influence over both civil and public spheres, plays a key role in normalizing the atrocities perpetrated against Falun Gong. The branches of the Office convey antiFalun Gong messages through the manipulation of cultural activities, education, exhibitions and grassroots events by the likes of women and youth organizations. ${ }^{157}$ For example, school children are taken to see anti-Falun Gong exhibitions. In Shannan township, students were made to watch recordings of Falun Gong practitioners recanting their faith following the transformation process. ${ }^{158}$ In post-secondary education, a condition of admission is that students must prove that they have adopted the "correct attitude" on Falun Gong. ${ }^{159}$ Neighbourhood associations are instructed to hold study sessions to "unify their thinking" against Falun Gong. ${ }^{160}$ The perpetrator's perspectives are thus being continuously reinforced upon the populace through schools, workplace, media, academic and popular culture.

The 610 Office has leveraged its extensive authority to make anti-Falun Gong work as a routine and integral task for state and public institutions. The eradication campaign against Falun Gong has become a social institution and an element of social order itself. ${ }^{161}$ An example of such institutionalization is the integration of forced organ harvesting into the health system of the state. With the 610 Office as intermediary, the public security system operating in a chain of command with the judiciary, hospitals and civil affairs administration has forcibly procured organs from Falun Gong practitioner. ${ }^{162}$ After more than a decade of operation, the act of forced organ harvesting - an extraordinary cruelty - has been institutionalized and normalized as a healthcare policy.

The final cause of normalization we mention is the inculcation of cruelty and violence through the history and culture of the Chinese Communist Party. Under the Party's philosophy of dou zheng, ${ }^{163}$ violence and cruelty are legitimized and glorified as a means of emancipation and

\footnotetext{
${ }^{155}$ Douglas Litowitz, “Gramsci, Hegemony, and the Law,” BYU Law Review 2000, no. 2 (2000), 526.

${ }^{156}$ Ibid., 529.

${ }_{157}$ World Organization to Investigate the Persecution of Falun Gong, Investigative Report on the 610 Office, September 8, 2003, updated on February 1, 2011, accessed August 20, 2017, http://www.upholdjustice.org/ node/197.

${ }^{158}$ Noakes and Ford, Managing Political Opposition Groups, 671.

${ }^{159}$ Ibid.

${ }^{160}$ Ibid., 666.

${ }^{161}$ Kilgour et al., Bloody Harvest/The Slaughter, 396 (Figure 12.2).

${ }^{162}$ Ibid., 408.

${ }^{163}$ The concept of "dou zheng", synonymous with "struggle" in English, is fundamental to Chinese Communist ideologies in both political and spiritual terms. Mao stated that "political power grows out of the barrel of a gun" (Source: Mao Tsetung, Quotations from Chairman Mao Tse Tung (Beijing: Foreign Languages Press, 1966).)
} 
self-fulfillment. Started with Mao's leadership, the Party has adopted dou zheng and violence as the source of political power. As Mao notoriously said, "battle with heaven, fight with the earth, struggle (dou zheng) with humans - therein lies endless joy."164 Violence employed by the Party not only serves as the means to seize and maintain power. The continuous use of violence justifies violence. By creating a political culture of violence through regular use of violence and supporting propaganda, the Party creates a society where violence is taken for granted. ${ }^{165}$

Outside of this context, the genocide against Falun Gong may appear anomalous in what seems like an era of peace and prosperity in China. If we keep in mind the Party history and culture, we can see that the genocide of Falun Gong takes on the form of past violent projects which have persisted throughout the history of Chinese communist rule. The forced labour camps, brainwashing centres, and many of the torture methods applied on Falun Gong practitioners were inherited from past practices. One can observe striking parallels between the attack on Falun Gong and the Party's "counter-revolutionary" movements in the past, such as the Three Anti and Five Anti Campaign, Antiright Movement, and the Cultural Revolution. ${ }^{166}$ The modus operandi for each campaign is similar: first, the regime designates the victim group with a derogatory label such as enemy of the State or counter-revolutionary to incite hatred and antagonism among the populace. Intensive nationwide media denunciations and condemnations of the victim group follow suit. Thereafter, the victim group is arrested in large numbers. The regime then runs secret courts, fabricates accusations, ransacks homes, and interrogates through torture. ${ }^{167}$ When such behaviour towards societal outcasts is built into the culture and fabric of the society through constant repetition, citizens end up accepting these campaigns as the normal, expected, treatment of outcasts. As a result, citizens fail to see the violence and atrocities as the genocide that it truly is. The horror of genocide hides behind the normalized, casual application of violence inflicted on those the state defines as enemies. A habitual application of a stimulus results in numbness towards that stimulus. That numbness is the sensory equivalent of societal normalization.

\section{The Issue of Classification}

The classification of the anti-Falun Gong campaign as a cold genocide does pose some difficulties. These difficulties stem in part from the fluidity and sophistication of the cold genocide framework. In the case of Falun Gong, these difficulties arise also from the continuously evolving nature of the eradication campaign. In particular, the intent and motives demonstrated by the perpetrators against Falun Gong are more typical of a hot, rather than a cold genocide. This is especially so at the earlier phase of the eradication campaign. In a cold genocide, the destruction of the victim group has been seen by scholars as "inevitable rather than imperative." 168 Is that the case for Falun Gong?

On the one hand, the regime's imperative is to eradicate Falun Gong completely. The destruction of Falun Gong is directly, consciously and deliberately sought. The intensity of violence, damage and hate exemplified in the anti-Falun Gong campaign is remarkably higher than found in the archetypical cold genocide seen in the colonial and post-colonial context. There are anti-Falun Gong directives circulated among the state and party organizations. The determination to destroy Falun Gong was well publicized in the years 1999 to 2001. After that, the campaign quieted down within China, but according to the paper trails provided by Ford and Noakes, the regime remained determined to destroy Falun Gong. On the other hand, there is no law banning Falun Gong. The

Like Marx, Mao also perceives "struggle" as the basis of happiness and spiritual fulfillment (Source: San Xiao,

The Youth of Comrade Mao Zedong (Liaoning: People's Publisher, 1951), 33.) Mao went as far as to theorize

"struggle" as the physical manifestation of "contradiction" that underpins all matter and existence (Source:

“On Contradiction, August 1937," Selected Works of Mao Tse-tung, Marxists Internet Archive, accessed

February 18, 2018, https://www.marxists.org/reference/archive/mao/selected-works/volume-1/mswv1 17.htm.

${ }^{164}$ The Youth of Comrade Mao Zedong. An alternative translation is "Fighting with heaven, fighting with earth, and fighting with human being, what a great pleasure!"

${ }^{165} \mathrm{Chu}$, The Counterrevolution, 73.

${ }^{166}$ Ibid.

${ }^{167}$ This pattern is described as typical ritual by Chu, The Counterrevolution, 77.

${ }^{168}$ Anderson, Colonialism and Cold Genocide, 20. 
610 office is a Party and not a State office. The regime has taken a sequence of steps against Falun Gong, which, if effective, would lead inevitably to its eradication. The Falun Gong are like fish in a net, without a chance to escape.

In any case, there are important features in the campaign against Falun Gong that can only be explained with the framework of a cold genocide. One such feature is the effort to destroy Falun Gong simultaneously on physical, spiritual and social planes. In this campaign, biological destruction is not paramount, but only a component in a larger scheme of complete eradication. As well, the anti-Falun Gong campaign evolved to develop dynamics that are atypical of hot genocide, but peculiar to cold genocides - subtlety and normalization. While we acknowledge the limitations in our characterization of Falun Gong as a cold genocide, we believe that the inquiry into the form of genocide to which Falun Gong has succumbed should not be a mere classification exercise. Genocides are, by nature, complex phenomena. To fit these events into watertight compartments is likely to restrict, rather than advance, our understandings of such mass crimes. In a spirit of critical inquiry, we consider the analytical structures in genocide studies to remain dynamic and fluid.

\section{Conclusion}

A critical inquiry into the concept of genocide challenges the classical school of genocide which focuses on biological death and body counts. ${ }^{169}$ A critical inquiry also encourages exploration of new areas which have been marginalized. The genocide against the Falun Gong, on account of its scale, cruelty and sophistication, is a preeminent human rights disaster of the 21st century. Yet, this attack has thus far been poorly understood and is underrepresented in genocide studies.

It is possible to analyse the eradication campaign against Falun Gong within the classical framework of genocide. But such a framework fails to appreciate the invisible, non-physical elements of eradication which make the attack insidious, potent and deadly. We have sought to make sense of this eradication campaign through an alternative framework inspired by Anderson's concept of cold genocide. Our central contention is that the eradication of Falun Gong is a cold genocide because its elaborate underpinning of ideology and masking have led to a genocide which features multidimensionality, subtlety and normalization. These three features identify Falun Gong as a cold genocide. At the same time, they also provide explanations why the campaign against Falun Gong is underrepresented in genocide studies and is able to sustain for such a lengthy period.

The critical inquiry of the genocide of Falun Gong opens ways for scholars to appreciate new dynamics and nuances in state crimes. Falun Gong is not the only group that has been attacked by the Chinese communist regime. But it has become the primary target of eradication. The Party has invested a large amount of China's resources in the campaign. ${ }^{70}$ The present inquiry also provides a fresh interpretive lens which allows us to make sense of the persecution of other groups in China. ${ }^{171}$ Genocide studies, in substance, are studies of extreme intolerance. Genocide studies should be responsive to the evolving manifestations of this intolerance. Definitions and theories of genocide should respond to this reality. Some aspects of the campaign against Falun Gong do not easily fit into the traditional classifications. The eradication campaign against Falun Gong has distinctive features. The purpose of the article is not just to apply traditional classifications to the Falun Gong eradication campaign but also to spark a discussion on the limits of those classifications in light of this campaign.

While the purpose of the article is scholarship, we would be remiss if we did not also add, in light of our analysis, a call to action. The eradication campaign of Falun Gong has persisted for eighteen years, with little opposition outside the Falun Gong community. It is well past time for the international community to take a stand on this eradication campaign and take steps to end the abuse. A study of an ongoing genocide cannot be only a theoretical discourse. All should try to end it. Cold genocides are slow. There is plenty of time for response. Nonetheless, combatting a cold

\footnotetext{
${ }^{169}$ James Snow, “Claudia Card's Concept of Social Death: A New Way of Looking at Genocide," Metaphilosophy 47, no. 4-5 (2016), 608, accessed May 25, 2017, doi: 10.1111/meta.12209.

${ }^{170}$ Zhang, Pouring the Entire Nation's Efforts into Persecution, 63.

${ }^{171}$ There are comparable measures in the Chinese regime's strategies to eradicate the Falun Gong and Tibetan. Anderson, Colonialism and Cold Genocide, 14.
} 
genocide requires identification, understanding and transcendence of the culture of hostility which accompanies the physical destruction. Otherwise, all countermeasures, all aid and rescue, will be too late, conducted postmortem, after the devastation is complete.

\section{Acknowledgements}

This article is dedicated to the Chinese citizens who were innocently killed for their spiritual beliefs.

\section{Appendix A}

\begin{tabular}{|c|c|c|c|c|c|}
\hline Country/Region & $\begin{array}{l}\text { Time of } \\
\text { Genocide }\end{array}$ & Duration & Victim Group(s) & $\begin{array}{c}\text { Estimated numbers of } \\
\text { victims }\end{array}$ & Source \\
\hline $\begin{array}{l}\text { Ottoman Empire } \\
\text { (present day Turkey, } \\
\text { Syria \& Irag) }\end{array}$ & $1915-1923$ & 8 years & Armenians & 1.5 million & $\begin{array}{l}\text { Totten \& Parsons, } 4 \text { th } \\
\text { edition, } 132 .\end{array}$ \\
\hline $\begin{array}{l}\text { Ukraine (Holodomor: } \\
\text { The Soviet Made Famine } \\
\text { in Ukraine) }\end{array}$ & $1932-1933$ & 1 year & Ukrainians & 5- 7 million & $\begin{array}{l}\text { Totten \& Parsons, } 4 \text { th edition, } \\
157 \& 166 .\end{array}$ \\
\hline $\begin{array}{l}\text { Germany and Europe (The } \\
\text { Holocaust) }\end{array}$ & $1939-1945$ & 6 years & $\begin{array}{l}\text { Mostly Jews, but also } \\
\text { Gypsies (Romas), mentally } \\
\text { and disabled people, and } \\
\text { others }\end{array}$ & $\begin{array}{l}\text { 5-6 million Jews, } 130,000 \\
\text { Gypsies, } 275,000 \text { people with } \\
\text { disabilities. }\end{array}$ & $\begin{array}{l}\text { Totten \& Parsons, 3rd edition, } \\
129 \& 131 \text {; and } 4 \text { th edition, } \\
191 .\end{array}$ \\
\hline $\begin{array}{l}\text { Bangladesh (committed by } \\
\text { Pakistani armed forces) }\end{array}$ & 1971 & 9 months & $\begin{array}{l}\text { Bengalis (Hindus and mostly } \\
\text { Muslims) p. } 256 \\
\end{array}$ & 3 million & $\begin{array}{l}\text { Totten \& Parsons, } 4 \text { th edition, } \\
250 .\end{array}$ \\
\hline $\begin{array}{l}\text { East Timor (committed by } \\
\text { Indonesian military forces) }\end{array}$ & 1975-1999 & 24 years & Timorese & $\begin{array}{l}\text { No precise account due to } \\
\text { absence of demographic records; } \\
\text { but according to Ben Saul, over } \\
200,000 \text { East Timorese had been } \\
\text { killed }\end{array}$ & $\begin{array}{l}\text { Totten \& Parsons, 4th edition, } \\
287-288 \text {; Saul, 477-479. }\end{array}$ \\
\hline $\begin{array}{l}\text { Cambodia - Democratic } \\
\text { Kampuchea }\end{array}$ & $1975-1979$ & 4 years & $\begin{array}{l}\text { Buddhists, Muslim Cham, } \\
\text { Vietnamese, and Chinese } \\
\text { (and anyone who was not of } \\
\text { the Cambodian race), and part } \\
\text { of the majority national } \\
\text { (Khmer) groups }\end{array}$ & 1.7 million & $\begin{array}{l}\text { Totten \& Parsons, } 4 \text { th edition, } \\
317 .\end{array}$ \\
\hline $\begin{array}{l}\text { Iraq (The Anfal Operations } \\
\text { in Iraqi Kurdistan) }\end{array}$ & $\begin{array}{l}\text { February to } \\
\text { September, } 1988\end{array}$ & 8 months & Kurdish civilians & $50,000-200,000$ & $\begin{array}{l}\text { Totten \& Parsons, } 4 \text { th edition, } \\
395,399 \text { \& } 401 \text {. }\end{array}$ \\
\hline Rwanda & 1994 & 100 days & Tutsi & $500,000-1,000,000$ & $\begin{array}{l}\text { Totten \& Parsons, } 4 \text { th edition, } \\
447 .\end{array}$ \\
\hline $\begin{array}{l}\text { Bosnia - Genocide in } \\
\text { Bosnia Herzegovina }\end{array}$ & 1992-1995 & 3 years + & $\begin{array}{l}\text { Bosnian Serbs and Bosnian } \\
\text { Croats attempted to remove } \\
\text { the other and Bosnian } \\
\text { Muslims }\end{array}$ & $10,000-20,000$ & $\begin{array}{l}\text { Totten \& Parsons, } 4 \text { th edition, } \\
478 .\end{array}$ \\
\hline Sudan-Darfur & 2003 - present & $\begin{array}{l}\text { Likely } \\
\text { ongoing }\end{array}$ & $\begin{array}{l}\text { Black Africans/Non-Arabs } \\
\text { (Muslims) }\end{array}$ & $300,000-400,000$ & $\begin{array}{l}\text { Totten \& Parsons, 4th edition, } \\
513 .\end{array}$ \\
\hline China & 1999 - present & Ongoing & $\begin{array}{l}\text { Chinese citizens who practice } \\
\text { Falun Gong }\end{array}$ & $\begin{array}{l}\text { Inconclusive (estimates range } \\
\text { from } 100,000 \text { to over one million) }\end{array}$ & \\
\hline
\end{tabular}

\section{Bibliography}

Allison, Kirk, Arthur Caplan, Michael E. Shapiro, Charl Els, Norbert W. Paul, and Huige Li. "Historical Development and Current Status of Organ Procurement from Death Row Prisoners in China." BMC Medical Ethics 16, no. 85 (2015): 1-7. Accessed February 10, 2017. https://doi.org/10.1186/s12910-015-0074-0

Amnesty International. People's Republic of China: Human Rights in China in 2001- A New Step Backwards. Briefing, September 3, 2001. Accessed March 20, 2017. https://www.amnesty. org/download/Documents/128000/asa170282001en.pdf.

. China: "Changing the Soup but not The Medicine?" Abolishing Re-education through Labour in China. London: Amnesty International Publications, December 17, 2013. Accessed November 20, 2017. https://www.amnesty.org/en/documents/ASA17/042/2013/en/.

An, Ni, Yuanyuan Shi, Yabo Jiang, and Linlin Zhao. "Organ Donation in China: The Major Progress and the Continuing Problem." The Journal of Biomedical Research 30, no. 2 (2016): 81-82. Accessed August 30, 2017. https://doi.org/10.7555/JBR.30.20150160

Anderson, Kjell. "Colonialism and Cold Genocide: The Case of West Papua." Genocide Studies and Prevention: An International Journal 9, no. 2 (2015): 9-25. Accessed December 12, 2016. https://doi.org/10.5038/1911-9933.9.2.1270 
Armillei, Riccardo, Nikki Marczak, and Panayiotis Diamadis. "Forgotten and Concealed: The Emblematic Cases of the Assyrian and Romani Genocides." Genocide Studies and Prevention: An International Journal 10, no. 2 (2016): 98-120. Accessed March 25, 2017. https://doi. org/10.5038/1911-9933.10.2.1404

Bates, Thomas R. "Gramsci and The Theory of Hegemony." Journal of the History of Ideas 36, no. 2 (1975): 351-366. Accessed September 8, 2017. https://doi.org/10.2307/2708933

Bejesky, Robert. “United States Obligations under International Law and the Falun Gong v. Jiang Zemin Lawsuit: A Justified Reaction to a Threat to Public Security or Genocide? You Decide." Journal of International Law \& Policy 11, no. 2 (2005): 295-342.

Card, Claudia. "Genocide and Social Death." Hypatia 18, no. 1 (2003): 63-79. https://doi. org/10.1111/j.1527-2001.2003.tb00779.x

Chang, Maria Hsia. Falun Gong: The End of Days. New Haven: Yale University Press, 2004.

Cheung, Maria. "The Intersection between Mindfulness and Human Rights: The Case of Falun Gong and Its Implications for Social Work." Journal of Religion \& Spirituality in Social Work: Social Thought 35, no. 1-2 (2016): 57-75.

$\mathrm{Chu}$, Yuan-Horng. "The Counterrevolution-A Family of Crimes: Chinese Communist Revolutionary Rhetoric, 1929-89." In The Web of Violence: From Personal to Global, edited by Jennifer Turpin and Lester R. Kurtz, 69-89. Chicago: University of Illinois Press, 1997.

Cook, Sarah and Leeshai Lemish. "The 610 Office: Policing the Chinese Spirit." Jamestown Foundation China Brief 11, no. 17 (2011): 6-9. Accessed May 17, 2017. https://jamestown.org/program/ the-610-office-policing-the-chinese-spirit/.

Crandall, Jedidiah R., Masashi Crete-Nishihata, Jeffrey Knockel, Sarah McKune, Adam Senft, Diana Tseng, and Greg Wiseman. "Chat Program Censorship and Surveillance in China: Tracking TOM-Skype and Sina UC." First Monday: Peer-reviewed Journal on the Internet 18, no. 7 (2013): n.p. Accessed November 26, 2017. http://firstmonday.org/ojs/index.php/fm/ article/viewArticle/4628/3727.

Doctors Against Forced Organ Harvesting. "Implausible Medical Examinations of Falun Gong Forced Labor Camp Workers in China." August 10, 2014. Accessed January 30, 2017. http://www.dafoh.org/articles-and-reports/implausible-medical-examinations-falungong-forced-labor-camp-workers.

--------. "Unusual Course of Organ Donation Registry Numbers in China." January 15, 2017. Accessed August 30, 2017. https://dafoh.org/articles-and-reports/unusual-course-of-organdonation-registry-numbers/.

Edelman, Bryan and James Richardson. "Falun Gong and the Law: Development of Legal Social Control in China." Nova Religio: The Journal of Alternative and Emergent Religions 6, no. 2 (2003): 312-331. https://doi.org/10.1525/nr.2003.6.2.312

Falun Dafa Information Center. "Mechanics of Persecution." April 9, 2015. Accessed February 10, 2017. http://faluninfo.net/topic/7.

--------. "Overview of Falun Gong." April 2008. Accessed December 20, 2016. http://www. faluninfo.net/topic/22.

Freedom House. The Battle for China's Spirit: Religious Revival, Repression, and Resistance under Xi Jinping. Special Report, February 2017. Accessed April 29, 2017. https://freedomhouse.org/ report/china-religious-freedom/falun-gong.

Gutmann, Ethan. The Slaughter: Mass Killings, Organ Harvesting, and China's Secret Solution to Its Dissident Problem. New York: Prometheus Books, 2014.

Hedges, Paul. "A Review of the Religion of Falun Gong." Journal of Buddhist Ethics 21 (2014): 700-705.

Hinton, Alexander Laban. "Critical Genocide Studies." Genocide Studies and Prevention 7, no. 1 (2012): 4-15. https://doi.org/10.3138/gsp.7.1.4

Huang, Jiefu, Yilei Mao, and J Michael Millis. "Government Policy and Organ Transplantation in China." The Lancet 372, Issue 9654, no. 6-12 (2008): 1937-1938. Accessed February 10, 2017. https://doi.org/10.1016/S0140-6736(08)61359-8

Human Rights Law Foundation. "Jiang Zemin and the Party's Douzheng Campaign Against Falun Gong." May 6, 2015. Accessed December 12, 2016. http://en.minghui.org/html/ articles/2015/5/6/150033.html. 
Jekielek, Jan. "Google Exit Highlights China's Most Censored Internet Topic: Falun Gong." The Epoch Times, March 26, 2010. Accessed November 30, 2017. https://www.theepochtimes. com/hlights-chinas-most-censored-internet-topic-falun-gong 1515779.html.

Junker, Andrew. "Follower Agency and Charismatic Mobilization in Falun Gong." Sociology of Religion 75, no. 3 (2014): 418-441. Accessed February 20, 2017. https://doi.org/10.1093/ $\underline{\text { socrel/sru021 }}$

Kilgour, David, Ethan Gutmann, and David Matas. "Bloody Harvest/The Slaughter - An Update." V2, June 2016. Accessed August 26, 2016 to September 7, 2017. endorganpillaging.org/ wp-content/uploads/2016/06/Bloody Harvest-The Slaughter-June-23-V2.pdf. From 2018 forward accessed at https://endtransplantabuse.org/an-update/.

Lee, Nathan. "Covert or Die: Forced Religious Conversions and the Convention on the Prevention and Punishment of the Crime of Genocide." Georgetown Journal of International Law 47, no. 2 (2016): 573-606.

Hongzhi, Li. "Lecture at the First Conference in North America." Lecture, New York, March 29- 30, 1998. Accessed September 12, 2017. http://en.falundafa.org/eng/lectures/19980329L.html.

-------. "Some Thoughts of Mine." FalunDafa, June 2, 1999. Accessed May 12, 2017. http:// falundafa.org/eng/eng/jiyz2 02.htm.

Liaoning. "Police from Multiple Areas Force Blood Tests on Falun Gong Practitioners at Their Homes." Minghui, July 5, 2014. Accessed December 2, 2017. https://www.minghui.org/ mh/s/2014/7/5/\%E5\%A4\%9A\%E5\%9C\%B0\%E8\%AD\%A6\%E5\%AF\%9F\%E4\%B8\%8A\%E9 \%97\%A8\%E9\%80\%BC\%E8\%BF\%AB\%E6\%B3\%95\%E8\%BD\%AE\%E5\%8A\%9F\%E5\%AD\% A6\%E5\%91\%98\%E9\%AA\%8C\%E8\%A1\%80-294315.html

Litowitz, Douglas. “Gramsci, Hegemony, and the Law." BYU Law Review 2000, no. 2 (2000): 515-551.

Lowe, Scott. "Chinese and International Contexts for the Rise of Falun Gong." Nova Religio: The Journal of Alternative and Emergent Religions 6, no. 2 (2003): 263-276. https://doi.org/10.1525/ nr.2003.6.2.263

Marxists Internet Archive. "On Contradiction, August 1937." Selected Works of Mao Tse-tung. Accessed February 18, 2018. https://www.marxists.org/reference/archive/mao/selectedworks/volume-1/mswv1 17.htm.

Matas, David. "Numbers." In State Organs: Transplant Abuse in China, edited by David Matas and Torsten Trey, 77-93. Niagara Falls: Seraphim Editions, 2012.

Matas, David and David Kilgour. Bloody Harvest: The Killing of Falun Gong for Their Organs.Niagara Falls: Seraphim Editions, 2009.

. Report Into Allegations of Organ Harvesting of Falun Gong Practitioners in China. July 6, 2006. Accessed September 3, 2017. http://organharvestinvestigation.net/report0607/ report060706-eng.pdf.

Matas, David and Maria Cheung. "Concepts and Precepts: Canadian Tribunals, Human Rights and Falun Gong." Canadian Journal of Human Rights 1, no. 1 (2012): 62-91.

Minghui. "Clearwisdom Collection: Illustrations of Torture Methods Used to Persecute Falun Gong Practitioners (Part II)." Clearwisdom, August 30, 2004. Accessed February 12, 2017. http://www.clearwisdom.net/emh/articles/2004/8/30/51887p.html.

Minghui Correspondent. "4126 Deaths Confirmed." Clearwisdom, September 6, 2017. Accessed September 6, 2017. http://www.clearwisdom.net/html/index.html.

Minghui Correspondent in China. "10,869 Cases of Falun Gong Practitioners Arrested and Harassed for Their Faith Reported in the First Half of 2017." Clearwisdom, November 6, 2017. Accessed November 15, 2017. http://en.minghui.org/html/articles/2017/11/6/166305.html

---------. "The Economic Persecution of Falun Gong Practitioners in Beijing." Clearwisdom, March 23, 2004. Accessed December 2, 2017. http://www.en.minghui.org/html/ articles/2014/3/23/146039p.html.

-------. "Persecution Continues Unabated after Labor Camp Closures (Part 1)." Clearwisdom, January 18, 2014. Accessed March 20, 2017. http://en.minghui.org/html/articles/2014/1/18/ 144478p.html.

Minghui Library. Statistics and Charts of Persecution from 1999-2017 (Chinese). Accessed November 15, 2017. http://library.minghui.org/category/2,418 „1.htm\#G2. 
Noakes, Stephen and Caylan Ford. "Managing Political Opposition Groups in China: Explaining the Continuing Anti-Falun Gong Campaign." The China Quarterly 223 (2015): 658-679. Accessed August 20, 2017. https://doi.org/10.1017/S0305741015000788

North Spring Edit. Letter from Comrade Jiang Zemin to Standing Members and Related Leaders of the Political Bureau of the CCCP. April 27, 1999. Beijing Spring. Accessed March 3, 2017. http://beijingspring.com/bj2/2001/60/2003727210907.htm.

. "Speech of Comrade Jiang Zemin at the Central Political Bureau Meeting on Seizing the Solution and Solving the 'Falungong' Issue." Speech, June 7, 1999. Bejing Spring, July 27, 2003. Accessed March 3, 2017. http://beijingspring.com/bj2/2001/60/2003727210907.htm.

Nowak, Manfred. Mission to China: Report of the Special Rapporteur on Torture and Other Cruel, Inhuman or Degrading Treatment or Punishment. March 10, 2006. UN Doc. E/CN.4/2006/6/ Add.6. Accessed February 7, 2017. http://www.dafoh.org/wp-content/uploads/UNSpecial-Rapporteur-Manfred-Nowak Mission-to-China 2006.pdf.

Ownby, David. Falun Gong and the Future of China. New York: Oxford University Press, 2008. https://doi.org/10.1093/acprof:oso/9780195329056.001.0001

Paul, Norbert W., Arthur Caplan, Michael E. Shapiro, Charl Els, Kirk C. Allison, and Huige Li. "Human Rights Violations in Organ Procurement Practice in China." BMC Medical Ethics 18, no. 11 (2017): 1-9. Accessed March 20, 2017. https://doi.org/10.1186/s12910-017-0169-x

Penny, Benjamin. The Religion of Falun Gong. Chicago: The University of Chicago Press, 2012. https://doi.org/10.7208/chicago/9780226655024.001.0001

Rosenberg, Sheri P. "Genocide Is a Process, Not an Event." Genocide Studies and Prevention: An International Journal 7, no. 1 (2012): 16-23. Accessed December 12, 2016. http://scholarcommons.usf.edu/gsp/vol7/iss1/4.

Saul, Ben. "Was the Conflict in East Timor 'Genocide' and Why Does it Matter?" Melbourne Journal of International Law 2, no. 2 (2001): 477-522.

Schabas, William A. Genocide in International Law: The Crime of Crime. 2nd ed. New York: Cambridge University Press, 2009. https://doi.org/10.1017/CBO9780511575556

Snow, James. "Claudia Card's Concept of Social Death: A New Way of Looking at Genocide." Metaphilosophy 47, no. 4-5 (2016): 607-626. Accessed May 25, 2017. https://doi.org/10.1111/ meta.12209

Stanton, Gregory H. “What is Genocide?” Genocide Watch, 2002. Accessed December 18, 2016. http://www.genocidewatch.org/genocide/whatisit.html.

Stop Organ Harvesting in China. "A State Crime." Accessed February 20, 2018. http://www. stoporganharvesting.org/a-state-crime/.

Tang, En. "Twelve Years after the Tiananmen Self-immolation Hoax, More and More People Understand the Truth." Clearwisdom, March 7, 2013. Accessed February 10, 2017. http://en.minghui.org/html/articles/2013/3/7/138396.html.

Tong, James W. Revenge of the Forbidden City: The Suppression of the Falun Gong in China, 1999-2005. New York: Oxford University Press, 2009. https://doi.org/10.1093/ acprof:0so/9780195377286.001.0001

Totten, Samuel and William S. Parsons. Centuries of Genocide: Essays and Eyewitness Accounts, 4th ed. New York: Routledge, 2013.

---------. Centuries of Genocide: Critical Essays and Eyewitness Accounts, 3rd ed. New York: Routledge, 2009.

Trey, Torsten. "Unprecedented Evil behind Forced Organ Harvesting: The Choice to Die Spiritually or Physically." In An Unprecedented Evil Persecution: A Genocide Against Goodness in Humankind, edited by Torsten Trey and Theresa Chu, 122-131. USA: Clear Insight Publishing, 2016. https://doi.org/10.7590/245227717X15090911046557

"Transplant Medicine at a Crossroads: Unethical Organ Procurement Practices in China." in State Organs: Transplant Abuse in China, edited by David Matas and Torsten Trey, 16-26. Niagara Falls: Seraphim Editions, 2012.

Trey, Torsten and David Matas. "State-organized Criminal Forced Organ Harvesting." Journal of Trafficking and Human Exploitation 1, no. 2 (2017): 175-186.

Tsetung, Mao. Quotations from Chairman Mao Tse Tung. Beijing: Foreign Languages Press, 1966. 
United Nations General Assembly. International Covenant on Civil and Political Rights. December 16, 1966.

United Nations Office of the Special Adviser for the Prevention of Genocide and the Responsibility to Protect. "Definitions: Genocide." Accessed November 30, 2017. http://www.un.org/en/ genocideprevention/genocide.html.

United States Commission on International Religious Freedom. 2017 Annual Report. April 26, 2017. Accessed April 29, 2017. http://www.uscirf.gov/sites/default/files/2017. USCIRFAnnualReport.pdf.

United States Department of Justice, Office of Public Affairs. "Justice Department Resolves Discrimination Case Against Flushing, N.Y. Restaurant That Ejected Patrons Because of Religion." Justice News, August 12, 2010. Accessed September 10, 2017. https://www. justice.gov/opa/pr/justice-department-resolves-discrimination-case-against-flushing-nyrestaurant-ejected.

Washington Post. "The Great Firewall of China: Keywords Used to Filter Web Content." February 18, 2006. Accessed November 30, 2017. http://www.washingtonpost.com/wp-dyn/content/ article/2006/02/18/AR2006021800554.html.

"What's Behind the Organ Donation in China Being Second in the World." Xinhua Daily News, December 1, 2017. Accessed February 10, 2018. http://www.xinhuanet.com/201712/01/c 1122039703.htm.

World Organization to Investigate the Persecution of Falun Gong. Investigative Report on the 610 Office. September 8, 2003 (Updated on February 1, 2011). Accessed August 20, 2017. http://www.upholdjustice.org/node/197.

-------. Investigative Report on the Chinese Communist Regime's 'Educational Transformation Decisive Battle' Policy of the Persecution of Falun Gong. August 11, 2014. Accessed November 30, 2017. https://www.zhuichaguoji.org/node/43884\# Toc394744064.

Xia, Yiyang. "Brainwashing: Extermination of Mind and Body." In An Unprecedented Evil Persecution: A Genocide Against Goodness in Humankind, edited by Torsten Trey and Theresa Chu, 80-94. USA: Clear Insight Publishing, 2016.

--------. "The Illegality of China's Falun Gong Crackdown-and Today's Rule of Law Repercussions." Written Statement submitted by Senior Director of Policy and Research at the Human Rights Law Foundation to European Parliament, 2011. Accessed April 25, 2017.http://www.europarl.europa.eu/meetdocs/2009 2014/documents/droi/dv/506 yiyangxia 506 yiyangxia en.pdf.

Xiao, San. The Childhood and Youth of Comrade Mao Zedong. Liaoning: People's Publisher, 1951.

Yu, He. "Former 610 Office Head Li Dongsheng Indicted." Clearwisdom, August 29, 2015. Accessed February 10, 2017. http://en.minghui.org/html/articles/2015/8/29/152297.html.

Zhang, Tianliang. "Pouring the Entire Nation's Efforts into Persecution." In An Unprecedented Evil Persecution: A Genocide Against Goodness in Humankind, edited by Torsten Trey and Theresa Chu, 63-74. USA: Clear Insight Publishing, 2016. 